\title{
KOŚCIÓŁ PW. ŚW. JAKUBA I KLASZTOR BONIFRATRÓW W LUCKU W OPISIE WIZYTACYJNYM Z 1832 ROKU
}

\begin{abstract}
Streszczenie
Bonifratrzy zostali sprowadzeni do Łucka w 1638 roku z inicjatywy kanonika kapituły łuckiej ks. Baltazara Tyszki przy poparciu biskupa łuckiego Andrzeja Gembickiego. Wybudowany wówczas kościół pw. św. Marii Magdaleny i klasztor nie przetrwały jednak pożaru, który ogarnął Łuck we wrześniu 1781 roku. Postanowiono wówczas przekazać bonifratrom inny, XVI-wieczny kościół św. Jakuba w zamian za plac, na którym stał dotychczasowy konwent. Dokument fundacji przekazanego kościoła pw. św. Jakuba nie jest znany. Wiadome jest natomiast, że był on kościołem parafialnym do czasu oddania go bonifratrom. Przedstawiony opis kościoła i klasztoru bonifratrów w Łucku powstał w 1832 roku w ramach wizytacji z polecenia biskupa łuckiego i żytomierskiego Michała Jana Piwnickiego i został spisany przez kanonika katedralnego łuckiego, Michała Sylwestrowicza. Rękopis źródłowy jest obecnie przechowywany w Państwowym Archiwum Obwodu Żytomierskiego w Żytomierzu pod sygnaturą: fond. 90, op. 1, sp. 1011. Tekst zapisany jest w języku polskim. Pismo jest czytelne, regularne i staranne, bez skreśleń i poprawek. Akt wizytacji składa się z 16 stron. Edycja tekstu została przeprowadzona wedle zasad instrukcji wydawniczej dla źródeł historycznych od XVI do połowy XIX wieku autorstwa Kazimierza Lepszego, wydanej w 1953 roku w Warszawie.
\end{abstract}

Słowa kluczowe: Łuck; kościół pw. św. Jakuba; bonifratrzy; wizytacja kanoniczna

\section{Wstęp}

Opis kościoła pw. św. Jakuba oraz klasztoru bonifratrów w Łucku na podstawie wizytacji pasterskiej z 1832 roku nie ukazał się do tej pory drukiem. Dostępne są natomiast inne teksty źródłowe i opracowania dotyczące w sposób bezpośred-

* Sławomir Romański-Cebula - dr nauk humanistycznych w dziedzinie religioznawstwa; adiunkt na Wydziale Historii i Dziedzictwa Kulturowego Uniwersytetu Papieskiego Jana Pawła II w Krakowie; e-mail: slawomir.cebula@upjp2.edu.pl

https://orcid.org/0000-0003-0629-4196 
ni lub pośredni łuckiego konwentu. Wśród nich na szczególną uwagę zasługuje publikacja Marii Dębowskiej: Łacińska parafia pod wezwaniem św. Jakuba Apostoła w Łucku (XV-XVIII w. $)^{1}$ zawierająca historię interesującej nas świątyni wraz z dodanymi w aneksie dokumentami (m.in. opisem wizytacji generalnej z 1799 roku $)^{2}$. Wartymi odnotowania są również badania Jana Marka Giżyckiego, który pisze o wizytacji z $1818 \mathrm{roku}^{3}$, M. Dębowska zaś wspomina o wszystkich trzech wcześniejszych wizytacjach $(1799,1818$ i 1820), które są przechowywane w Państwowym Archiwum Obwodu Żytomierskiego w Żytomierzu ${ }^{4}$, ostatnią z nich opracowując w publikacji Kościót i klasztor bonifratrów tuckich w świetle wizytacji generalnej z $1820 \mathrm{roku}^{5}$. Kolejny chronologicznie, prezentowany poniżej opis z 1832 roku jest ważny co najmniej z trzech powodów. Po pierwsze, wypełnia lukę w dostępnych dokumentach dotyczących łuckiego kościoła i klasztoru bonifratrów. Po drugie, stanowi ostatni znany dokument wizytacyjny przed kasatą zakonu bonifratrów w Łucku w 1843 roku oraz późniejszym pożarem, w którym ucierpiał zarówno Łuck, jak i sam kościół. Zamyka w ten sposób ponad dwuwiekową historię łuckich bonifratrów. Po trzecie, z kościoła i klasztoru bonifratrów w Łucku do dzisiaj nie zachowały się żadne zabudowania: budynki klasztorne przebudowano na mieszkania, a kościół w połowie XIX wieku stał się ruiną, która nie przetrwała do kolejnego stulecia ${ }^{6}$. Zatem wyłącznie dokumenty stanowią dziś źródło do badań nad łuckim konwentem bonifratrów.

Dokument fundacji kościoła pw. św. Jakuba nie jest znany. Wiemy jedynie z przywileju Zygmunta Augusta dla kościoła św. Jakuba Apostoła w Łucku z 8 maja 1545 roku, że zaginął on w czasie najazdu tatarskiego, pożaru bądź innego kataklizmu? . Wiadome jest natomiast, że kościół św. Jakuba był kościołem parafialnym do czasu oddania go bonifratrom ${ }^{8}$.

Bonifratrzy zostali sprowadzeni do Łucka z inicjatywy kanonika kapituły łuckiej Baltazara Tyszki przy poparciu arcybiskupa Łucka Andrzeja Gembickiego w 1638 roku. Budowę klasztoru i kościoła pw. Św. Marii Magdaleny rozpoczęto rok później, w 1639 roku. Było to możliwe dzięki zapisom ks. B. Tyszki, który w trosce o biednych i chorych zapisał na ten cel znaczne środki: 8000 złotych zabezpieczone na łuckim kahale żydowskim oraz 5000 złotych zabezpieczone na

${ }^{1}$ M. Dębowska, Lacińska parafia pod wezwaniem św. Jakuba Apostoła w Łucku (XV-XVIII w.), Lublin 2014.

${ }^{2}$ Tamże, s. 147-150.

${ }^{3}$ J.M. Giżycki, Zniesione kościoły i klasztory rzymsko-katolickie przez rząd rosyjski $w$ wieku XIX-tym w diecezji tuckiej, żytomierskiej i kamienieckiej (gub. Wotyńskiej, kijowskiej i podolskiej), „Nova Polonia Sacra”, 1 (1928) s. 204.

${ }^{4}$ Dębowska, Lacińska parafia, s. 11.

${ }^{5}$ Por. M. Dębowska, Kościól i klasztor bonifratrów łuckich w świetle wizytacji generalnej z 1820 roku, w: Universitati serviens. Księga pamiątkowa ku czci Księdza Profesora Stanisława Wilka $S D B$, red. J. Walkusz, M. Krupa, Lublin 2014, s. 85-94.

${ }^{6}$ Stownik geograficzny Królestwa Polskiego i innych krajów stowiańskich, red. F. Sulimierski, B. Chlebowski, W. Walewski, Warszawa 1884, t. 5, s. 778-792.

${ }^{7}$ Dębowska, Lacińska parafia, s. 125-133.

${ }^{8}$ Tamże, s. 47. 
dobrach wsi Mirków i innych należących do Michała Myszki Chołoniewskiego9. W zamian bonifratrzy byli zobowiązani do odprawiana 54 mszy rocznie oraz ratowania chorych ${ }^{10}$. Wybudowany kościół i klasztor nie przetrwały jednak pożaru, który ogarnął Łuck we wrześniu 1781 roku. Postanowiono wówczas przekazać bonifratrom inny, XVI-wieczny kościół św. Jakuba w zamian za plac, na którym stał dotychczasowy konwent.

Przedstawiony poniżej opis kościoła i klasztoru Bonifratrów w Łucku powstał w 1832 roku w ramach wizytacji z polecenia biskupa łuckiego i żytomierskiego Michała Jana Piwnickiego i został spisany przez kanonika katedralnego łuckiego Michała Sylwestrowicza. Rękopis źródłowy jest obecnie przechowywany w Państwowym Archiwum Obwodu Żytomierskiego w Żytomierzu pod sygnaturą: fond. 90, op. 1, sp. 1011. Tekst zapisany jest w języku polskim. Pismo jest czytelne, regularne i staranne, bez skreśleń i poprawek. Na szesnastu stronach znajdujemy kolejno: opis kościoła i klasztoru; opis folwarku należącego do łuckich bonifratrów; inwentarz zakrystii; sprzęty kościelne z kruszcu; wykaz kościelnej cyny, miedzi i mosiądzu; wykaz ksiąg i sprzętów kościelnych; opis porządku nabożeństw; wykaz naczyń i sprzętów znajdujących się w klasztorze i infirmerii; wykaz obrazów; wykaz sprzętów gospodarskich, pojazdów, uprzęży i dobytku; opis bielizny infirmerii i refektarza; sumariusz dokumentów; tabelę sum funduszowych konwentu; tabelę przychodu rocznego klasztoru; opis służby klasztornej; opis infirmerii i chorych; tabelę obligów kościoła bonifratrów oraz rejestr imienny osób zakonnych. W dokumencie nie podano dokładnej daty wizytacji. Informacja ze strony $13 \mathrm{v}$ o podliczeniu przychodów konwentu do dnia 11 października 1832 roku ${ }^{11}$ wskazuje, że wizytacja mogła odbywać się właśnie wtedy.

Akt wizytacji zawiera „Summariusz Dokumentów” zgromadzonych w klasztorze, czyli opis kluczowych dokumentów związanych z fundacją i zabezpieczeniem środków na funkcjonowanie konwentu. Znajdujemy tam informacje o akcie zamiany kościoła św. Marii Magdaleny na kościół św. Jakuba z 1783 roku, inwentarze wizyt $\mathrm{z}$ lat 1817-1832, księgi kongregacyjne ${ }^{12}$, akt fundacyjny konwentu bonifratrów ze środków przekazanych przez kanonika łuckiego Baltazara Tyszki z 1 marca 1639 roku $^{13}$ oraz jego potwierdzenie przez biskupa Andrzeja Gębickiego z 20 marca 1639 roku $^{14}$. Następnie wyszczególnione są liczne zapisy poczynione na rzecz konwentu łuckich bonifratrów w latach jego funkcjonowania, wyliczenia komisji za reskryptem Króla Stanisława Augusta długów na kahałach $^{15}$, nakazy sądów grodzkich, ziemskich i guberni dotyczące spraw majątko-

\footnotetext{
${ }^{9}$ Państwowe Archiwum Obwodu Żytomierskiego w Żytomierzu (dalej: DAŻO), f. 90, op. 1, sp. 1011, k. 7v, Akt wizyty kościoła i klasztoru OO. Bonifratrów tuckich za rok 1832 uczyniony, Summariusz dokumentów, Artykuł 1, No 1.

${ }^{10}$ Tamże.

${ }^{11}$ Tamże, k. 13v.

${ }^{12}$ Tamże, k. $5 \mathrm{v}$.

${ }^{13}$ Tamże, k. $7 \mathrm{v}$.

${ }^{14}$ Tamże, k. $7 \mathrm{v}-8$.

${ }^{15}$ Tamże, k. 8.
} 
wych związanych z konwentem ${ }^{16}$, nakazy konsystorzy dotyczące zapłat na rzecz bonifratrów ${ }^{17}$. Oprócz opisu wszystkie sumy funduszowe ujęte są osobno w tabelę $\mathrm{z}$ informacjami o kwocie, procentach, fundatorze oraz czasie pobierania lub zalegania z wpłatami ${ }^{18}$. Roczne przychody klasztoru podliczone pomiędzy 17 grudnia 1831 a 11 października 1832 roku wyniosły $3228 \mathrm{zł}$. W tym czasie dokonano wydatków (rozchodów) na utrzymanie zakonników, sług i chorych oraz na naprawy budynków w wysokości 2993,15 zł, a w kasie klasztoru pozostawało 234,15 zł ${ }^{19}$. $\mathrm{Z}$ kolei tabela obligów pokazuje, jakie zobowiązania ciążyły na łuckich bonifratrach. Głównie było to odprawianie mszy świętych w intencjach darczyńców: Ks. Baltazara Tyszki (intencja - za jego duszę) - 54 msze rocznie; Felicjana i Dominika Dubieńskich (intencja - za ich dusze) - 12 mszy rocznie; Samuela i Katarzyny Szaniawskich Steckich (intencja - za ich dusze) - 24 msze rocznie; Zachariasza Jana Szulca (intencja - za jego duszę oraz dusze jego rodziców) - 52 msze rocznie; Aleksandra Łubienieckiego (intencja - za jego duszę) - 12 mszy rocznie $^{20}$. Oprócz wymienionych odprawiano również z przepisu konstytucji zakonnej msze za zmarłych księży, braci, krewnych, przyjaciół i dobrodziejów zakonu - 52 msze rocznie oraz msze za każdego katolika umierającego w szpitalu oraz każdego umierającego zakonnika -2 msze rocznie ${ }^{21}$. Łączna liczba mszy, do których byli zobligowani w 1832 roku łuccy bonifratrzy, wynosiła 208.

Opis kościoła rozpoczyna się od zaznaczenia nieznajomości jego fundatora oraz informacji, że dawniej był parafialnym, a od 1782 roku w wyniku zamiany został przekazany bonifratrom ${ }^{22}$. Następnie autor przechodzi do szczegółowego opisu świątyni, przedstawiając na początku jego wygląd: od zachodu i rzeki Styr prowadziły do kościoła wielkie drzwi, od południa zaś mniejsze. Z kolei od północy do kościoła przymurowana była zakrystia i kaplica. W kościele znajdowało się sześć ołtarzy. Główny składał się z trzech części: na górze był obraz św. Jakuba Apostoła - patrona świątyni, nieco niżej drewniany krucyfiks „łaskami słynący”, pod nim zaś obraz Najświętszej Maryi Panny trzymającej w ręku Pana Jezusa. Po obu stronach ołtarza znajdował się chór zakonny, drewniany. Po bokach kościoła autor opisuje dwa ołtarze „,podobnej struktury wielkiemu ołtarzowi”: od strony zakrystii z wizerunkiem Najświętszej Maryi Panny piastującej maleńkiego Jezusa trzymającego w ręku trzy srebrne strzały, od strony ambony zaś - św. Józefa trzymającego maleńkiego Jezusa. W kaplicy od strony północnej stały dwa ołtarze: św. Augustyna i św. Jana Bożego, czyli świętych związanych z zakonem bonifratrów (poświęcone twórcy reguły oraz założycielowi zakonu). Wreszcie po drugiej stronie znajdował się ostatni ołtarz - św. Rafała. Pod arkadą sklepienia umieszczony był duży krucyfiks, a od strony południowej drewniana ambona. Nad drzwiami znajdował się chór z pozytywem o sześciu głosach. Kościół był

\footnotetext{
${ }^{16}$ Tamże, k. 8, 11.
}

${ }^{17}$ Tamże, k. 9v, 11.

${ }^{18} \mathrm{~K}$ Tamże, k. 13.

${ }^{19}$ Bilans kasowy się nie zgadza, różnica wynosi 70 gr, co może być przyczyną błędu rachunkowego wizytatora. Tamże.

${ }^{20}$ Tamże, k. 15.

${ }^{21}$ Tamże.

${ }^{22}$ Tamże, k. 1 
otynkowany na biało, z ceglaną posadzką w nawie i nową drewnianą podłogą w prezbiterium i zakrystii. Cmentarz pod kościołem opisano zdawkowo: „groby zawalone"23. Podobnie jak w poprzednich opisach wizytacyjnych napisano, że w kościele znajdowało się 6 okien: 4 większe i 2 mniejsze. Ławek było 6 . Kościół pokryty był gontem. "Ze strony facjaty dach jest wyższy, niższy zaś z tyłu ${ }^{24 ”}$. Ogólny stan świątyni podsumowano następująco: „Kaplica również i kościół po zgorzeniu wiele reparacji potrzebują, nie tylko [z] zewnątrz ale nawet i wewnątrz, gdzie miejscami znacznie poopada225".

W zakrystii położonej od strony północnej przechowywano szaty liturgiczne. Akt wizytacyjny wymienia 25 różnego rodzaju ornatów ${ }^{26}$, dwie kapy ${ }^{27}, 9$ korporałów ${ }^{28}, 3$ komże, 15 alb, 6 antependiów ${ }^{29}, 10$ firanek, 6 humerałów ${ }^{30}, 36$ puryfikaterzy $^{31}, 5$ pasków, 6 poduszek pod mszały, 11 ręczników, szal muślinowy do noszenia Najświętszego Sakramentu i 12 tuwalni ${ }^{32}$ na ołtarzach.

Osobno odnotowano sprzęty kościelne z kruszców i metali. Na wyposażeniu kościoła były następujące wyroby ze srebra: dwie ampułki, tacka, aniołek do monstrancji, blacha do ładownicy, figura z tablicą i trupią głową pod nogami, kielich srebrny wyzłacany, 4 kielichy srebrne wewnątrz wyzłacane, 7 koron, w tym 3 z promieniami, kubek, łyżeczka do komunii unickiej, puszka srebrna wyzłacana, zepsuta puszka, 4 pateny, pacyfikał ${ }^{33}$, sukienka na obrazie św. Jana Bożego, sukienka w małym obrazie Najświętszej Maryi Panny, strzały Pana Jezusa, 3 turybularze ${ }^{34}$ czy 59 wotów srebrnych. Ponadto zapisano wiele przedmiotów z cyny, miedzi i mosiądzu ${ }^{35}$, a także księgi kościelne w liczbie $12^{36}$.

Porządek nabożeństw wyznaczający rytm życia konwentu wyglądał w 1832 roku następująco: codziennie o 5 rano odbywał się chór $\mathrm{z}$ medytacją, a o 8 rano

${ }^{23}$ Tamże, k. 2.

${ }^{24}$ Tamże.

${ }^{25}$ Tamże.

${ }^{26}$ Tamże, k. 3v.

${ }^{27}$ Tamże.

${ }^{28}$ Korporał (łac. corporale) - obrus o wymiarach $50 \times 50 \mathrm{~cm}$, będący elementem bielizny kielichowej, na którym podczas celebracji Mszy św. ustawiane są kielich, patena oraz cyborium.

${ }^{29}$ DAŻO, f. 90, op. 1, sp. 1011, k. 4, Akt wizyty.

${ }^{30}$ Humerał (łac. humeralis) - biała, podłużna chusta, stanowiąca element stroju liturgicznego, okrywająca ramiona kapłana, zawiązywana na piersi, nakładana przed włożeniem ornatu.

${ }^{31}$ Puryfikaterz - element bielizny kielichowej, stanowiący niewielki kawałek materiału (niewielki ręcznik) służący do czyszczenia naczyń liturgicznych.

${ }^{32}$ Tuwalnia - welon naramienny, tkanina używana podczas przenoszenia Najświętszego Sakramentu.

${ }^{33}$ Pacyfikał (łac. pacificale, pacificus) - pokój czyniący; sprzęt liturgiczny w Kościele katolickim z pojemnikiem lub pojemnikami na relikwie.

${ }^{34}$ Trybularz (łac. turibulum, thuribulum) - metalowa szkatułka zamocowana na łańcuszkach i zamykana przykrywką, w której znajduje się metalowy koszyczek wypełniony rozżarzonymi bryłkami węgla drzewnego, które posypuje się ziarenkami kadzidła, służąca do okadzania podczas obrzędów liturgicznych.

${ }^{35}$ DAŻO, f. 90, op. 1, sp. 1011, k. 4v, Akt wizyty...

${ }^{36}$ Tamże. 
msza święta z litanią lub hymnem do św. Jana Bożego. Z kolei nieszpory zakonne odmawiane były o 3 po południu.

Klasztor opisany został jako budynek:

o jednem [s] piętrze z dachem i sklepieniem na dwa wchody [s] i dwoje sieni składające, jakoby dwa domy złączone. Przez jednym onego wchodem $[s]$ jest galeria, z której idąc do pierwszej sieni, wprost drzwi do kuchni, za którą stancja i spiżarnia. Po prawej stronie cela przełożonego zakonnego, przy której jest garderóbka na skład różnych rzeczy, z sieni zaś w lewą cela zakonna, w prawą refektarz, gdzie jest stół i szafa kredensowa. $\mathrm{Z}$ tego refektarza wchod $[s]$ po lewej stronie do celi zakonnej, po prawej do celi przełożonego. W drugim przedziale domu jest ganek, $\mathrm{z}$ którego wchod $[s]$ do stancji o czterech małych pokoikach i garderóbką. Klasztor ten cały gontami jest pobity. Drzwi, okna $\mathrm{z}$ kratami i piece wszędzie podług potrzeby mające ${ }^{37}$.

Występują tu nieznaczne zmiany w stosunku do opisów poprzednich wizytacji, jak np. za kuchnią w opisie obecnym nie znajdowała się już „piekarnia i spiżarnia”, lecz „stancja i spiżarnia ${ }^{38 ” . ~ N a ~ u w a g e ̨ ~ z a s ł u g u j a ̨ ~ s z c z e g o ́ ł o w o ~ o p i s a n e ~}$ księgi w ogólnej liczbie 91 woluminów ${ }^{39}$. Jeśli zaś chodzi o obrazy malowane na płótnie, podano tylko ich ogólną liczbę $-7^{40}$.

W rogu podwórza znajdującego się za wejściem do klasztoru jest „dom zamieszkały przez słabych, czyli infirmeria”, która opisana jest następująco:

Okien w niej z boku jest 2, z frontu zaś 3 i piec kaflowy, obraz, szafa na infirmaria $[s]$, kredens. Izba ta ma łóżek 6 wygodnie wystawionych. Usługa dla tych chorych dopełnioną bywa przez zakonników dniem i nocą. Na drugiej stronie jest izba do mycia tymże chorym bielizny $\mathrm{z}$ alkierzem do złożenia ich rzeczy. W pierwszej izbie są dwa okna, w alkierzu zaś jedno z kratą ${ }^{41}$.

Podczas wizytacji w 1832 roku w szpitalu bonifratrów łuckich zajęte były cztery z sześciu łóżek. W opisie znajdujemy informacje o imionach i nazwiskach objętych opieką, ich wieku, wyznaniu, statusie społecznym, chorobie i czasie kuracji. Przebywali tam wówczas: Felia Szaszewicz, lat 33, wyznania rzymskokatolickiego, stanu szlacheckiego wolnego, cierpiąca na manie i przebywająca w szpitalu od 25 listopada 1829 roku; Anton Czerczyk, lat 20, wyznania unickiego, parobek przebywający w szpitalu z powodu kołtuna polskiego i róży, pozostający pod opieką od 25 września 1829 roku; Adam Radziński, lat 67, wyznania rzymskokatolickiego, furman, cierpiący z powodu odmrożenia, w infirmerii od 19 listopada 1831 roku oraz Józef Arnet, lat 12, pochodzenia szlacheckiego, „ograniczony umysłowo” przebywający w szpitalu od 28 lipca 1832 roku. Informacje te wskazują na ówczesny charakter szpitali, będący po części przytułkami, w których podopieczni przebywali latami.

Akt wizytacyjny zawiera również szczegółowe informacje o naczyniach i sprzęcie znajdującym się w klasztorze i szpitalu, począwszy od zastaw stoło-

\footnotetext{
${ }^{37}$ Tamże, k. 2-2v.

${ }^{38}$ Por. Dębowska, Lacińska parafia, s. 69.

${ }^{39}$ DAŻO, f. 90, op. 1, sp. 1011, k. 5, Akt wizyty.

${ }^{40}$ Tamże.

${ }^{41}$ DAŻO, f. 90, op. 1, sp. 1011, k. 2v, Akt wizyty.
} 
wych i wyposażenia kuchennego, poprzez sprzęt gospodarski, aż po meble ${ }^{42}$. Wśród sprzętu szpitalnego obok 6 drewnianych, malowanych łóżek, spis wymienia 4 stoliki, 6 stołków, 7 spluwaczek, 6 tubek na jedzenie, dwie szafy na bieliznę, 1 na lekarstwa i 1 na skład zió ${ }^{43}$ oraz pokaźny zapas bielizny ${ }^{44}$. W szpitalu znajdowała się również mensa na kształt ołtarza, $\mathrm{z}$ umieszczonymi nad nią malowanymi na płótnie obrazami św. Anny i św. Mikołaja oraz drugi obraz Najświętszej Maryi Panny ${ }^{45}$.

Podobnie jak w poprzednich opisach wizytacyjnych odnotowano również stojącą dzwonnicę z trzema kamiennymi dzwonami wmurowaną w parkan. Natomiast $\mathrm{w}$ rogu południowym dziedzińca wspomniano o murowanym domu mającym „drzwi, okna, piece podług potrzeby”. Pomiar placu kościelnego wykazał liczbę podobną do tej z 1820 roku, a mianowicie 9176 i 1/8 łokci kwadratowych $\left(1820-9176 \mathrm{i} \frac{1}{2}\right)^{46}$. Podobnie również opisano ogrodzenie placu kościelnego:

Strona położona ku północy dziedzińca, tudzież strona wchodzenia do miasta i część południowej strony za klasztorem jest opasana murem, reszta zaś placu całego jest oparkaniona [s] drzewem rżniętym. Od Styru palami obita ${ }^{47}$.

W 1832 roku dokonano również pomiaru placu od facjaty kościoła do rzeki Styr, podając wartość 10080 łokci kwadratowych. Opisano również budynek po północnej stronie między infirmerią a ogrodem owocowym: szopa duża na siano i stajnia przy murze pokryta słomą i z drewnianymi wrotami opatrzonymi mocnymi zamkami ${ }^{48}$. Łuccy bonifratrzy dysponowali dwiema bryczkami z okuciem: krytą i niekrytą, karę do wożenia drew, uprzęże, lejce, uzdy, chomąta, a także 4 konie „różnej maści ${ }^{49}$. Dowiadujemy się również, że ogród owocowy i warzywny na „placu” pomiędzy facjatą kościoła a Styrem powstał na miejscu chałupek, które spłonęły w pożarze 1804 roku oraz że „plac rzeczony i całe obejście kościoła i klasztoru zajmujący jest niezmiernie w niskiem [s] położeniu, jako bliski rzeki Styru, a zatem bardzo wilgotny ${ }^{50 "}$. Następnie w dokumencie wymienia się pozostałe place będące własnością bonifratrów: pierwszy w sposób mało precyzyjny - plac „niedaleko karmelitów” oraz drugi - większy „z ogrodem i sianożęcią niedaleko okopiska żydowskiego na przedmieściu Łucka, na których domy są własne posiadaczów [s]. Czynsz tylko z gruntu opłacają"51.

Nowością w stosunku do wcześniejszych opisów jest odnotowana informacja

${ }^{42}$ Tamże, k.6-6v.

${ }^{43}$ Tamże, k. 7.

${ }^{44}$ Tamże, k. 7v.

${ }^{45}$ Tamże, k. 6v.

${ }^{46}$ Tamże, k. 2v; por. Dębowska, Łacińska parafia, s. 65.

${ }^{47}$ DAŻO, f. 90, op. 1, sp. 1011, k. 3, Akt wizyty...; W 1820 roku zapis wyglądał następująco: „strona północna dziedzińca, tudzież strona wschodnia od miasta i części południowej strony za klasztorem jest opasana murem, reszta zaś placu całego ogrodzona jest płotem z chrustu”. Dębowska, Łacińska parafia, s. 66.

${ }^{48}$ DAŻO, f. 90, op. 1, sp. 1011, k. 3, Akt wizyty.

${ }^{49}$ Tamże, k. 7-7v.

${ }^{50}$ Tamże, k. 3.

${ }^{51}$ Tamże. 
o folwarku należącym do bonifratrów i znajdującym się 5 wiorst od Łucka obok traktu dubieńskiego. Folwark został zapisany zakonowi 1 lutego 1810 roku przez Jana Piotrowicza, a od 1828 roku był w posiadaniu [possessyi] Choynackich. Wśród zabudowań folwarcznych znajdują się: drewniany dom pokryty słomą, z zewnątrz otynkowany, złożony z czterech pokoi i piekarni, nowa stodoła, spichlerz i obora oraz szopa, której dach wymaga szybkiej naprawy. W sadzie folwarcznym rosło 300 drzew owocowych (małych i dużych). Przechowywano tam 40 korców żyta ozimego i 9 korców pszenicy ${ }^{52}$.

Opis podaje także szczegółowe informacje o zakonnikach mieszkających w klasztorze oraz sługach klasztornych. Dowiadujemy się, że w 1832 roku w konwencie łuckim przebywało 4 bonifratrów i 5 osób służby. Osoby duchowne to: Tadeusz Blekicki, urodzony w 1799 roku w Ciechanowcu, wstąpił do zakonu w 1822 roku, a w 1823 roku złożył profesję, uczył się łaciny i języka polskiego, sprawował funkcje szafarza, zastępcy przełożonego i przełożonego w konwencie wysokim $^{53}$, a od roku 1827 był przełożonym konwentu łuckiego; ksiądz Benedykt Gieryk, urodzony w 1769 roku w Warszawie, wstąpił do zakonu w 1787 roku, a w 1788 złożył profesję, uczył się łaciny, języka polskiego i niemieckiego oraz edukacji szkolnej, sprawował funkcję przeora w Mińsku w latach 1801-1824, a w czasie wizytacji w Łucku był kapelanem; Leon Szydłowski, urodzony w 1776 roku w Lidzie, wstąpił do zakonu w 1814 roku, a w 1827 złożył profesję, uczył się języka polskiego i edukacji domowej, od wstąpienia do zakonu był kwestarzem i szafarzem, a w czasie wizytacji infirmarzem; Florian Lawnicz, urodzony w 1810 roku w Rogowie, wstąpił do zakonu w 1828 roku, a w 1829 złożył profesję, uczył się języka polskiego i łaciny, był kolejno kwestarzem, infirmarzem, zastępcą przełożonego, a w czasie wizytacji ponownie kwestarzem ${ }^{54}$. Służbę w klasztorze pełnili natomiast: Jan Hniatiuk z Gródka, powiat łucki, lat 30, parobek; Kajetan Matusiewicz z Borzemca, powiat łucki, lat 17, „na usługach klasztornych”; Antoni Hnaczuk z Hulanik, powiat łucki, lat 30, furman; Anna Kozakiewiczowa z Włodzimierza, lat 40, kucharka; Marianna Parwacka z Łucka, lat 45, praczka.

$* * * * *$

Edycja tekstu została przeprowadzona według zasad instrukcji wydawniczej dla źródeł historycznych od XVI do połowy XIX wieku ${ }^{55}$. Interpunkcja tekstu została uzupełniona i dostosowana do współczesnych wymogów, głównie poprzez dodanie przecinków i kropek kończących zdanie. Ujednolicono również kropki przy zapisach skrótów (np. „OO. Bonifratrzy”). Bez adnotacji w tekście poprawione zostały: pisownia łączna i rozdzielna oraz wielkie i małe litery na początku poszczególnych wyrazów. Zapis spółgłoski ,j” oraz samogłosek „i” i „y” dostosowano do zasad współczesnej pisowni (tey - tej, zakrystya-zakrystia etc.),

${ }^{52}$ Tamże, k. 3v.

${ }^{53}$ Wysokie - obecnie miasto na terenie dzisiejszej Białorusi, w obwodzie brzeskim.

${ }^{54}$ Tamże, k. 16.

${ }^{55} \mathrm{~K}$. Lepszy, Instrukcja wydawnicza dla źródet historycznych od XVI do poł. XIX w., Warszawa 1953. 
a w odpowiednich miejscach wstawiono znaki diakrytyczne. Literę „x” w polskich słowach zastąpiono dwuznakiem „ks” (xiądz - ksiądz). Wyrazy kończące się ,em" czy „emi” (złotemi) pozostawiono jak w oryginalnym zapisie. Nie ingerowano również w słownictwo typowe dla epoki, opatrując je skróconym ,sic" w nawiasie kwadratowym [s]. Pisane dużą literą tytuły i zwroty grzecznościowe wyrażające szacunek do podmiotu bądź podmiotów opisywanych pozostawiono $\mathrm{w}$ oryginalnym brzmieniu. Również w przypadku podawanych dat zachowano pierwotny ich zapis. Skróty oraz brakujące części wyrazów uzupełniono, dodając je w obrębie nawiasów kwadratowych. Pozostawiono podkreślenia spisującego tekst wizytacji.

$* * * * *$

Akt wizyty kościoła i klasztoru OO. Bonifratrów łuckich za rok 1832 uczyniony

[k. 1]

Akt wizyty kościoła i klasztoru OO. Bonifratrów łuckich z polecenia JW. Michała Jana Piwnickiego biskupa łuckiego i żytomierskiego, uczonych Towarzystwa Honorowego członka, kanonicznego prawa i Ś[wię]tej Teologii Doktora, Orderów Ś[wię]tej Anny I-szej i Ś[więte]go Włodzimierza III-ciej klasy Kawalera, przez WJKs. Michała Sylwestrowicza kanonika katedralnego łuckiego, Assessora Rzymsko Katolickiego Duchownego Konsystorza łuckiego Ś[wię]tej Teologii Doktora za rok 1832 uczyniony.

Artykuł 1-szy

Opisanie kościoła i klasztoru

Kościół i klasztor murowany w mieście Łucku nad rzeką Styrem jest położony. Kościół ten czyim funduszem jest wystawiony nie ma wiadomości: to tylko pewna, że od założenia swego pod tytułem Ś[więte]go Jakuba zostaje i był dawniej parafialnym. Roku 1782 dnia 23 marca w zamian za plac z zabudowaniami BB. Bonifratrów przy ulicy do Klasztoru Ks.Ks. Karmelitów idącej położony, z mieszkaniem, z zabudowaniami,

[k. $1 \mathrm{v}]$

cmentarzem i jurydyką, która po zniszczeniu ogniem chat na niej sytuowanych obrócona jest na ogród. Kościół ten przez zamianę urzędownie [s] sporządzoną tymże Ojcom Bonifratrom jest oddany. Architektura onego jest starodawna, obrócony facjatą ku rzece Styrowi, na zachód ma wielkie stąd drzwi, a z drugiej strony od południa są drzwi mniejsze, któremi $[s]$ się wchodzi do kościoła, ze strony zaś północnej przymurowana jest zakrystia i kaplica. W tym kościele ołtarzów jest 6: w najprzód $[s]$ wielki ołtarz stolarskiej i snycerskiej roboty, marmurkowo malowany, w którym w górze jest obraz Ś[więte]go Jakuba Apostoła, po tym jest miejsce czerwonem suknem wybite, gdzie się mieści Pan Jezus Ukrzyżowany z drzewa rżnięty, łaskami słynący. Niżej tegoż krzyża jest obraz niewielki Najśw[iętszej] Panny trzymającej na ręku Pana Jezusa, poniżej mensa drewniana, na której stoi cyborium stolarskiej i snycerskiej roboty malowidłem ozdobione, 
w którem utrzymuje się Sanctissimum Sacramentum ${ }^{56}$. Ze strony Epistoły ${ }^{57}$ jest ambona drewniana stolarską i snycerską robotą robiona, część jej okryta kolorami, a część wyzłacana, wprost której kratki drewniane malowane kształtem galerii, oddzielające część pierwszą kościoła od wielkiego ołtarza suknem czerwonem $[s]$ przykryte, nad temi [s] w górze jest krucyfiks duży z drzewa pod arkadą sklepienia umieszczony. Na bokach kościoła są dwa ołtarze podobnej struktury wielkiemu ołtarzowi: ołtarz ze strony zakrystii drewniany stolarską i snycerską robotą sporządzony, marmurowo malowany, ma w sobie osobę Najśw[iętszej] Panny piastującej Pana Jezusa maleńkiego, trzymającego w ręku strzały srebrne. Ołtarz drugi ze strony ambony, w którym obraz św. Józefa trzymającego Pana Jezusa maleńkiego. Kaplica

[k. 2]

ze strony północnej ma ołtarzy dwa. Pierwszy z muru, snycerską robotą robiony, marmurkowo malowany, mający w sobie obraz Ś[więte]go Augustyna, drugi ołtarz dwom rogowym podobny, które się wyżej opisały, ma w sobie obraz Ś[więte] go Jan Bożego. Kaplica ta ma przy wchodzie [s] kratki podobne do kościelnych środkowych przed wielkim ołtarzem. Ku drzwiom wielkim jest także po lewej stronie ołtarz w którym obraz Ś[więte]go Rafała. Chór na arkadzie nad wielkiemi [s] drzwiami murowany, na którym stoi pozytyw dekorowany o 6-eściu głosach. Przed wielkim ołtarzem po obu stronach chór zakonny drewniany malowany. Cały kościół z kaplicą i zakrystią jest sklepiony, biało tynkowany. Posadzka w kościele jest ceglana, na prezbiterium i zakrystii drewniana, nowo ułożona. Groby zawalone. Ławek do siedzenia jest 6. Okien oświecających kościół większych 4, mniejszych 2. Zakrystia do kościoła ma drzwi stolarskiej roboty, na zawiasach i hakach żelaznych, zamkiem opatrzone, w której jest mensa o dziewięciu szufladach na ornaty, tudzież szafka na wierzchu do chowania kielichów. W tej zakrystii jest $\mathrm{z}$ kratami okien 2 . Kościół jest pokryty gontami płasko. Ze strony facjaty jest dach wyższy, niższy zaś z tyłu. Kaplica również i kościół po zgorzeniu wiele reparacji potrzebują, nie tylko $[z]$ zewnątrz ale nawet $\mathrm{i}$ wewnątrz, gdzie miejscami znacznie poopadał.

Klasztor ze strony północnej położony o jednem $[s]$ piętrze z dachem i sklepieniem na dwa wchody $[s]$ i dwoje sieni składające, jakoby dwa domy złączone, przez jednym onego wchodem $[s]$ jest galeria, z której idąc do pierwszej sieni, wprost drzwi do kuchni, za którą stancja i spiżarnia.

[k. 2v]

Po prawej stronie cela przełożonego zakonnego, przy której jest garderóbka na skład różnych rzeczy, z sieni zaś w lewą cela zakonna, w prawą refektarz, gdzie jest stół i szafa kredensowa. $Z$ tego refektarza wchod $[s]$ po lewej stronie do celi zakonnej, po prawej do celi przełożonego. W drugim przedziale domu jest ganek, z którego wchod $[s]$ do stancji o czterech małych pokoikach i garderóbką. Klasztor ten cały gontami jest pobity. Drzwi, okna z kratami i piece wszędzie podług potrzeby mające.

\footnotetext{
${ }^{56}$ Sanctissimum Sacramentum - łac. Najświętszy Sakrament.

${ }^{57}$ Od południa.
} 
Po prawej stronie od wchodu $[s]$ jest podwórze, w rogu którego wymurowany jest dom zamieszkany przez słabych, czyli infirmeria, w tym sieni, z których po prawej stronie jest wchod $[s]$ do izby dużej, pomieszczającej ubogich chorych. Okien w niej z boku jest 2, z frontu zaś 3 i piec kaflowy, obraz, szafa na infirmaria $[s]$, kredens. Izba ta ma łóżek 6 wygodnie wystawionych. Usługa dla tych chorych dopełnioną bywa przez zakonników dniem i nocą. Na drugiej stronie jest izba do mycia tymże chorym bielizny $\mathrm{z}$ alkierzem do złożenia ich rzeczy. W pierwszej izbie są dwa okna, w alkierzu zaś jedno z kratą.

W parkanie murowanym, wymurowana jest dzwonnica, na której dzwonów kamiennych 3 . W pośrodku zaś niej jest furta, którą się wchodzi na dziedziniec. Przy samej dzwonnicy idąc do miasta jest brama wjezdna $[s]$ na dziedziniec. Na lewej stronie, $w$ rogu południowym dziedzińca jest dom murowany mający drzwi, okna, piece podług potrzeby. Plac przed kościołem i na około niego i przed klasztorem składający dziedziniec obejmuje łokci kwadratowych 9.176 i 1/8.

Plac począwszy od facjaty kościoła aż do rzeki Styrze

[k. 3]

ciągnący się obrócony na ogród zamyka łokci kwadratowych 10 080. Strona położona ku północy dziedzińca, tudzież strona wchodzenia do miasta i część południowej strony za klasztorem jest opasana murem, reszta zaś placu całego jest oparkaniona $[s]$ drzewem rżniętym. Od Styru palami obita. Od strony północnej infirmeria przy ciągnącym się murze, aż do fruktowego ogrodu są zabudowania gospodarskie następujące: szopa duża na siano wraz ze stajnią przy murze postawioną, słomą pokryta i wrotami drewnianemi [s] z zamkami opatrzona, dość mocne.

Ze strony facjaty kościoła, aż do rzeki Styru jest także plac duży, na którym były chałupki, w których właściciele klasztorowi WW. OO. Bonifratrów czynsze wypłacali, te gdy w czasie pożaru w r[ok]u 1804 wydarzonego ogniem spłonęły. Całe ich obejście zajętem $[s]$ zostało na ogród fruktowy i warzywny. Plac rzeczony i całe obejście kościoła i klasztoru zajmujący jest niezmiernie w niskiem $[s]$ położeniu, jako bliski rzeki Styru, a zatem bardzo wilgotny.

Prócz wyż[ej] rzeczonego placu, ma jeszcze klasztor placów małych 2, niedaleko Karmelitów i 3-ci większy, z ogrodem i sianożęcią niedaleko okopiska żydowskiego na przedmieściu miasta Łucka, na których domy są własne posiadaczów [s]. Czynsz tylko z gruntu do klasztoru opłacają.

Opisanie Folwarku należącego do BB. Bonifratrów Łuckich o wiorst 5 od Łucka koło traktu dubieńskiego.

Folwark. Niegdyś szlachetny Jan Piotrowicz mając sumy tradycjami na polach miejskich zaliczone, a przez rezolucją Magistratu Łuckiego w zastawie zmienione. Te przez testament. r[ok]u 1810 [dnia] 1 lutego sporządzony i tegoż czasu w aktach ziemskich oraz magistrackich łuckich

[k. $3 \mathrm{v}]$ oblatowany ${ }^{58}$ na szpital bonifratrów łuckich zapisał w posiadanie jakowych pól. Klasztor tutejszy od daty testamentu zostaje.

\footnotetext{
${ }^{58}$ Oblatowanie - starop. przeniesienie aktu z niewłaściwych do właściwych akt.
} 
Zabudowanie Folwarczne.

Dom mieszkalny drewniany wewnątrz i zewnątrz otynkowany z 4-ch pokojów i piekarni składający się, słomą pokryty, dość dobry. Dalsze zaś zabudowania: stodoła, szpichlerz, obora, nowe. Szopa: dach zupełnie stary i reperacji rychłej potrzebują.

Ogród fruktowy składający się z drzew mających małych i dużych sztuk 300.

Wysiewu: ozimego żyta korcy - 40.

Pszenicy korcy - 9.

Takowy folwark od r[ok]u 1828 zostaje w possessyi [s] W[ielmożnych] Choynackich.

Artykuł 2-gi

Inwentarz Zakrystyjny

Ornatów białych z różnemi $[s]$ kolumnami

Ornat biały z dalmatykami cum omnibus requisitis ${ }^{59} \quad 3$

Ornatów czerwonych cum omnibus requisitis 5

Ornatów zielonych cum omnibus requisitis $\quad 7$

Ornatów fioletowych cum omnibus requisitis 2

Ornatżałobny

Kapabiała

Kapa żałobna

Korporałów

Komeszek

$\mathrm{Alb}$

Antepediów skórzanych w kwiaty wybijanych ${ }^{60}$

[k. 4]

Antepediów materialnych [s]

Bursa $^{61}$

Firanek materialnych $[s]$ różnokolorowych

Humerałów

Puryfikaterzów [s]

Pasków5,poduszekpodmszały 6.

Ręczników dużych 3, małych przy ołtarzach 8

Szal muszlinowy $[s]$ do noszenia Sanctissimum

Tuwalninaołtarzach

Sprzety kościelne w kruszcu

Ampułek srebrnych wyzłacanych 2, tacka takaż 1

Aniołek srebrny do Monstrancji

Aniołek takiż $[s]$ stopiony

Blacha od ładownicy srebrna

Figura srebrna $\mathrm{z}$ tablicą i trupią głową pod nogami na krzyżu mosiężnym . 1 (1) (1) 3

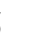


Kielich srebrny zupełnie wyzłacany

Kielichów wewnątrz tylko wyzłacanych

Koron srebrnych z promieniami

Korona u Pana Jezusa 1, w obrazie Ś[więte]go Jana Bożego 1, na statuach Najśw[iętszej] Panny Maryi i Pana Jezusa 2.

Kubeksrebrnyniewielki

Łyżeczka wyzłacana od Komunii unickiej

Monstrancja srebrna miejscami wyzłacana

Puszka srebrna cała wyzłacana

Puszka srebrna wewnątrz tylko zepsuta

Paten srebrnych wyzłacanych

Pacyfikał srebrny z relikwiami po obu stronach

Sukienka srebrna na obrazie Ś[wiete]go Jan Bożego

[k. 4v]

Sukienka na obrazie małym Najśw[iętszej] Panny Maryi w wielkim ołtarzu z promieniami w około głowy z gwiazdkami

Strzał dwie u Pana Jezusa

Turybularz srebrny z łódką i łyżeczką takiemiż [s]

Wotów srebrnych różnych figur i różnej wielkości

Wotów w kształcie serc w ołtarzu Ś[więte]go Jana Bożego

W ołtarzu nad głową Pana Jezusa i Ś[więte]go Józefa promienie srebrne, w ręku lilia i sandały na nogach u Ś[więte]go Józefa w ogóle

Cyna, miedź i mosiądz kościel[ne]

Cyna

Krucyfikscynowy niewielkizrelikwiami

Kanonów nowych par 3. starych par 6. detto 18

Kociołek cynowy na wodę święconą

Lichtarzów $[s]$ dużych parzystych par 11 detto

Lichtarzów [s] mniejszych parzystych par 4 detto

Lawaterz ${ }^{62} \mathrm{z}$ misą cynową 1 detto

Tacka cynowa $\mathrm{z}$ ampułkami szklanemi $[s]$

Miedź

Blachaotwierana miedziana pozłacana zwizerunkiem Najśw[iętszej] MaryiCzęstochowskiej

Kociołek miedziany na wodę święconą

Mosiądz

Lamparzmosiężny

Trybularz bez łódki mosiężny zepsuty

Forma do pieczenia opłatków

Forma do wyrzynania Hostji $[s]$ 1, do wyrzynania komunikantów 1. detto 2 Szczypce doobjaśniania świecżelazne

${ }^{62}$ Lawaterz (łac. lavatorium) - umywalnia dla kapłanów, zwykle stojąca w zakrystii i służąca do mycia rąk przed Mszą św., wykonana z marmuru, brązu, kamienia lub metali. 
Ksieggi i inne sprzęty kościelne

Mszałów świetnych dużych 3, mały 1 . detto

Mszałów rekwialnych 6, Agendka 1. detto

Ewangeliczka ${ }^{63}$

Krucyfiksów na ołtarzach drewnianych

[k. 5]

Krzyż drewniany do procesji

Lusterek w kształcie gwiazd z kompozycji robionych 2

Obrazów na płótnie malowanych

Sukno czerwone stare do nakrywania gradusów

Sukien do nakrywania ołtarzów $[s] \quad 5$

Materyi $[s]$ staroświeckiej do nakrywania ambony i ławek 3

$\begin{array}{lr}\text { Kwiatków w bukietach na ołtarze par 5. detto } & 10\end{array}$

$\begin{array}{ll}\text { Kwiatków starych takiejże roboty par 5. detto } & 10\end{array}$

Biblioteka

Brewiarzów [s] w skórę oprawionych 7, bez oprawy 2 detto 9

Do nabożeństwa książeczek małych, łacińskich $\quad 7$

Księgi pod tytułem doktorskie: ksiąg w różnych językach

Do nabożeństwa niemiecka 1, polskich 3. detto 4

Droga do życia pobożnego ${ }^{64}$

Droga do zbawienia 1

Drogadowieczności 1

Ekonomikapowszechna 2

Ewangeliczka 3

Głos Pana kruszącego cedry libańskie ${ }^{65} \quad 1$

Gramatyka łacińska 1

Góra Tabor 1

KościółChrystusów Wojujący ${ }^{66} \quad 1$

Katechizmów 2

Kronikipolskie 1

Kazań ksiąg $\quad 6$

KoncyliumTrydenckie $\quad 1$

MiastoŚwięte ${ }^{67} \quad 2$

Martyrologium łacińskie i polskie $\quad 2$

Medytacji 2

${ }^{63}$ Ewangeliczka - zbiór ewangelii czytanych z ambony w dni świąteczne.

${ }^{64}$ Prawdopodobnie: św. Franciszek Salezy, Filotea. Droga do życia pobożnego.

${ }^{65}$ O. Marcin Rubczyński, Głos Pana kruszącego cedry libańskie.

${ }^{66}$ O. Marcin Rubczyński, Kościót Chrystusów Wojujacy.

${ }^{67}$ Prawdopodobnie: Piotr Kwiatkowski SJ, Miasto Święte Niedościgłemi Taiemnicami Ubłogostawione. 
[k. $5 \mathrm{v}]$

Oratorpolityczny $^{68} \quad 1$

Prawdy wieczne

Porządek sądów i spraw miejskich ${ }^{69}$

Podróżdoziemiświętej

Przewodnik do Ojczyzny Niebieskiej ${ }^{70}$

Pismo Święte

Rozmyślania vel Lekcje Duchowne

Rozmowyteologa

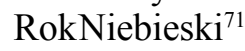

Różaniec z objawienia Nayśw[iętszej] Panny Maryi 1

Retoryka

Światło dróg Niebieskich ${ }^{72}$

Świątobliwość kapłana w Pietrze ${ }^{73}$

Teologii łacińskich 4, polskich 2 detto

Wiadomość o rzeczy zbawienia wiecznego ${ }^{74}$

Wyprawa człowieka do wieczności

Ksiąg łacińskich starych bez początku w jednostajnej oprawie pod różnym tytułem

Żywotów Ś[więte]go Jana

Żywoty wszystkich Świętych

Zbawienne Zabawy ${ }^{75}$

Opis zawierający zamianę klasztoru i kościoła Ś[wię]tej Maryi Magdaleny OO. Bonifratrów na kościół Ś[więte]go Jakuba i całą rezydencję r[ok]u 1783 uczyniony.

Inwentarzów [s] i wizyt z r[ok]u 1817 po 1832 rok w ciągłym porządku.

Ksiąg kongregacyjnych z r[oku] 1816 - 2, do zapisywania przychodów i rozchodów $\mathrm{z}$ lat dawnych 2 , infirmerskich 4 detto

[k. 6]

Porządek Nabożeństwa.

Każdego dnia z rana o godzinie 5-tej podług możności odbywa się chór z medyta-

${ }^{68}$ Prawdopodobnie: Kazimierz Woysznarowicz, Orator Polityczny Weselnym y Pogrzebowym Stuzacy Aktom: Tak Stanowi Duchownemu, iako Rycerskiemu potrzebny.

${ }^{69}$ Bartłomiej Groicki, Porządek sądów i spraw miejskich.

${ }^{70}$ Prawdopodobnie: Jan Bona, Przewodnik do Ojczyzny Niebieskiej.

${ }^{71}$ Prawdopodobnie: Rok niebieski albo przewodnik do szczęśliwey wiecznosci, Iezvsowi Królowi Niebieskiemv i Maryi Krolowey Niebieskiey.

72 Światło dróg niebieskich wielkiego w kościele Bożym luminarza Augustyna św. regułą i konstytucya św. Jana Bożego dla braci od miłosierdzia, w splendorze godnych imion przewielebnego w Bogu Oyca Franciszka Neuman prowincyała, y Wielebn. Oyców przeorów polskiej i litewskiej prowincyi tegoż zakonu, publicznemu na widok światu wystawiona przez $W(i e l) O.(j c a) R . B . K . W$. G. P. 1728 roku.

${ }^{73}$ Guil. Hauzen, Świątobliwość kapłana w Pietrze.

${ }^{74}$ Liboryusz Sinischalka, Wiadomość o rzeczy zbawienia wiecznego.

${ }^{75}$ Franciszek Ksawery, Zbawienne zabawy. 
cją, o godzinie 8-mej z rana Msza Ś[wię]ta podczas której śpiewają się Litania lub Hymn do Ś[więte]go Jana Bożego, o godzinie zaś 3-ciej po południu odmawiają się Nieszpory zakonne.

Naczynia i Sprzęty różne znajdujące się w klasztorze i infirmerii.

\section{Cyna}

Waza cynowa z nakrywką 1 , salaterka 1 , półmisek 1 . detto

Łyżek do wazy 3 , stołowych 30, do kawy 5. detto

Kuflów z nakrywkami 3, solniczek 2 detto

Przystawek

Lichtarzcynowy

Szerenga większa 1, szpryca maleńka 1 detto

Sztućców starych par 4, nowych par 15 detto

Miedź

Kociołek do grzania wody od 3-ch wiader

Kociołek do noszenia chorym jedzenia

Kociołek mały do grzania wody na herbatę

Rądelków [s] większych 3, mniejszych 4 detto

Baniak 1, dzbanek do wody 1 . detto

Imbryczek do kawy 1, druszlak [s] 1. detto

Łyżek do rozdawania jedzenia

Mosiądz:

Moździerz z thuczkiem

Lichtarzyków mosiężnych 3, szczypcy $[s] 2$, tacka 1. detto

Blacha:

Tac lakierowanych większa i mniejsza

Cukiernic 2, Skarbonek 2, Tarka 1. detto

Półgarcówka 1, kwarta 1. Lejek 1, Liwar 1 detto

Moździerz wyszczerbiony stary

Baniak niewielki 1, patelnia 1. detto

Fajans:

Waza duża z nakrywą 1 , małych bez nakrywek 2 . detto

[k. 6v]

Półmisków starych 3, nowych 2, blatów 2. detto

Talerzów [s] głębokich 21, płytkich 18

Maselniczka 1, cukiernica 1, miseczek 3

Imbryczków do herbaty

Kubeczków do kawy

Szkło:

Karafek

Szklanek 6, kieliszków 10

Butelekrozmaitegogatunku

Żelazo:

Siekier do rąbania drew

Piła poprzeczna 1, piłka ręczna 1, ogrodowych 2

Szatkownica do kapusty o trzech nożach 
Siekacz 1, nożów [s] kuchennych 4, rożen 1

Kruczek do ognia 1, widelec 1

Grac do ogrodu

Rydlów osadzonych

Kosastara

Drewniane:

Stół refektarski 1 , mały 1

Krzeseł z materacami 5, taboret 1, zydlów 2

Stolik czarny z szufladą w brąz oprawiony

Biurko takież z brązem

Sofapłótnemwybita

Stolików prostych, niewielkich

Tablatura do kominka

Szczotka do zamiatania cel

Łóżekprostych

W Infirmerii

Łóżek malowanych stolarskiej roboty

Stolików takichże

Stołków 6, pluwaczek 7

Tubki do noszenia jedzenia

Mensa z przykryciem na kształt ołtarza, nad którą obraz Ś[wię]tej Anny i Ś[więte] go Mikołaja na płótnie malowany 1, drugi Najświętszej Panny Maryi takoż na płótnie malowany mały 1

[k. 7]

Szafa z szufladami na bieliznę 1, na skład lekarstw 1, na bieliznę 1

Szafa na skład ziół z szufladami

Obrazy

Obrazów na płótnie malowanych

Krucyfiks za szkłem w ramkach

Obrazów półarkuszowych, także za szkłem

Landszaftów oprawnych za szkło, wyrażających historię syna marnotrawnego 12

Landszaftów także oprawnych wyrażających cztery pory roku

Lustrostaroświeckiew zakrystii 1,wcelioprawnewramysnycerskiejroboty 1, półarkuszowe

Zegar bijący w postumencie

Dzwonek

Tabliczka marmurowa do rachunków służąca

Sprzęty Gospodarskie

Sypań na zboże 6, tasek i wiader 6

Kadłubków 4, półbeczków na ogórki 2

Dzieżdochleba

Balej $[s] 1$, niecek 3

Żarna do robienia krup 1, ćwierć 1, łopata 1 


\section{Beczka na wodę}

Pojazdy

Bryczka niekryta z należytem [s] okuciem

Bryczka kryta kwestarska stara z przyzwoitem [s] okuciem

Kara do wożenia drew z okuciem

Kół okutych dobrych

Kółniekutychprostych

[k. 7v]

Uprzaż:

Szory $^{76}$ na koni $[s]$ drobnych $[s]$

Leyców [s] krzyżowych rzemiennych

Uzdeczek rzemiennych drobnych

Szlej ${ }^{77}$ rzemieniem obszytych 3, lejców 2

Uzdeczek rzemiennych

Chomątów [s] prostych 2, z nagrzbietnikami 1

Dobytek

Koniróżnejmaści

Bielizna Infirmerska

Poduszek pierzem nasypanych 14, kołder sukiennych 6

Prześcieradeł22, sienników 13

Szlafroków płóciennych 13, ręczników 9

Koszul dobrych 19, szlafmitu [s] 3

Nawleczek 39, firanka 1

Pończoch płóciennych par

Bielizna Refektarska

Obrusów dużych 3, mały 1, serwet dużych 3, małych 2

Summariusz Dokumentów

\section{Artykuł 1szy}

No 1.

Roku 1639 dnia 1 marca w Łucku od Baltazara Tyszki, kanonika łuckiego na dwie sumy 1-a 8000 zł kahale żydów łuckich, 2-a 5000 zł na dobrach Mirkowie $\mathrm{i}$ innych w JW. Michała Myszki Chołoniewskiego będących z obligiem odprawienia 54 Mszy na rok i ratowania codziennego chorych, przy trzech pieczęciach na wosku wyciśniętych na pergaminie zdziałany Fundusz.

No 2.

Roku 1639 dnia 20 marca od JW. Andrzeja Gębickiego ${ }^{78} \mathrm{z}$ potwierdzeniem funduszu od WJKs. Baltazara

[k. 8]

Tyszki, kanonika katedralnego łuckiego WW. Ojcom Bonifratrom uczynionego. Kościoła pod tytułem Ś[w]. Magdaleny, klasztoru i szpitala tychże WW. OO. Bonifratrów - erekcja

\footnotetext{
${ }^{76}$ Szory - uprząż końska w postaci szerokiego pasa zakładanego na pierś konia wraz z pomocniczymi rzemieniami.

${ }^{77}$ Szleja - najprostsza uprząż szorowa, zakładana koniowi na kark i pierś.

${ }^{78}$ Andrzej Gembicki - biskup łucki w latach 1638-1654.
} 


\section{No 3.}

Roku 1640 dnia 2 kwietnia ${ }^{79}$ w grodzie Łuckim od tegoż WJKs. Baltazara Tyszki, kanonika katedralnego łuckiego z rozporządzeniem swej substancji, mianowicie procentu od 8000 zł po $800 \mathrm{zł}$ przez Żydów łuckich do wypłacenia corocznie przyjętego, to jest aby WW. OO. Bonifratrom Konwentu Łuckiego tylko po 600 zł, a Księżom Jezuitom i katedralnym łuckim po 100 zł, wypłacano dysponujący i osobną sumę 15000 zł na mury tymże OO. Bonifratrom legujący w ekstrakcie będący. Testament

No 4.

Roku 1638 od kahału łuckiego na sumę 8000 z[łotych] OO. Bonifratrom Łuckim w Grodzie Łuckim roku tegoż d[nia] 13 czerwca ${ }^{80}$ oblatowany.

Zapis. No 5 .

Roku 1641, dnia 10 listopada ${ }^{81}$ w grodzie łuckim od WW. Felicjana i Dominika Dubińskich WW. OO. Bonifratrom Konwentu łuckiego na sumę 1000 zł z obligiem odprawiania co miesiąc po jednej Mszy Ś[więt]ey, oryginalny No 6.

Zapis

Roku 1790 dnia 26 lipca kategorii OO. Bonifratrów Konwentu łuckiego z protokołu komisji za reskryptem Króla Imć Stanisława Augusta w Łucku agitującej się, a do obliczenia długów na kahałach naznaczonej przyznający na kahale łuckim tymże OO. Bonifratrom sum dwie: 1-a 8000 zł, a 2-a 1000 zł.

Ekscerpt No 7.

Roku 1777 dnia 14 maja w sądach grodzkich łuckich między WW. OO. Bonifratrami konwentu łuckiego a kahałem łuckim nakazujący od tych sum przez

[k. 8v]

WJ. Księdza Tyszkę, kanonika łuckiego podług testamentu, jak i od 1000 złotych przez Dubińskich braci zapisanych, a w jedno zebranych z[łotych] 9000 zapłacenie prowizji należącej w ekstrakcie będący

Dekret

\section{Adnotacja do $\mathrm{Nu}[\mathrm{meru}] 1$-go}

Ponieważ kahał z sumy oryginalney 8000 zł przez Imć Księdza Tyszkę WW. OO. Bonifratrom konwentu łuckiego zapisany podług testamentowej pod N[umere]m 3-m położonej powinien był płacić sumy $2000 \mathrm{zł}$ procent katedrze łuckiej i Księżom Jezuitom łuckim, a zatem po rozdzieleniu funduszu zostało OO. Bonifratrom $\mathrm{z}$ tego zapisu na kahale rzeczonym zł 7000 .

Fascykuł 2-gi

No 1.

Roku 1670 dnia 3 czerwca $^{82}$ w Łucku między W. Jerzym na Horochowie Wielhorskim Podkomorzym Włodzimierskim z jednej a WW. OO. Bonifratrami konwentu łuckiego z drugiej strony 5000 zł przez J. Księdza Baltazara Tyszkę kanonika katedralnego łuckiego nadaną dóbr Klucza Horochowskiego wsi Mirkowa i innych przyjmujący prowizją za lat 20 do 2000 zł na oblig wyżej wyrażony obliczono zapewniający w oryginale będący

$\underline{\text { Kontrakt }}$

\footnotetext{
${ }^{79} \mathrm{~W}$ oryginale: Apryla

${ }^{80} \mathrm{~W}$ oryginale: Junii.

${ }^{81} \mathrm{~W}$ oryginale: Novembra.

${ }^{82} \mathrm{~W}$ oryginale: Junij.
} 
No 2.

Roku 1670 dnia 1 sierpnia $^{83}$ w grodzie łuckim od W. Jerzego na Horochowie Wielhorskiego, podkomorzego włodzimierskiego WW. OO. Bonifratrom konwentu łuckiego sumę 5000 zł z prowizją po 400 zł oznaczający wyderkafowy w ekstrakcie.

No 3.

Roku 1745 dnia 16 marca od W. Jerzego Olszańskiego,

[k. 9]

starosty owruckiego, na sumę złotych 5000 do śp. WJ. Księdza Baltazara Tyszki, kanonika katedralnego łuckiego WW. OO. Bonifratrom konwentu łuckiego zapisaną potem u W. Jerzego Wielhorskiego, podkomorzego włodzimierskiego będącą z dodatkiem od tychże WW. OO. Bonifratrom sumy zł 4000 z różnych jałmużn zebranej w ogóle na sumę złotych 9000 na Czarkowie lokowaną w aktach grodzkich łuckich na rzecz OO. Bonifratrów rzeczonych zeznany Zapis No 4.

Roku 1758 dnia 11 stycznia $^{84}$ z Dekretu Dzielczego między sukcesorami JW. O1szańskiego P[odkomorzego] W[łodzimierskiego] zł pol[skich] 9600 do dóbr miasteczka Mielnicy w powiecie kowelskim leżących przywiązującego co do kategorii WW. OO. Bonifratrów konwentu łuckiego z oblaty [s] tegoż dekretu w aktach grodzkich łuckich wyjęty

Fascykuł 3-ci

No 1.

Roku 1688 dnia 12 października ${ }^{85}$ w grodzie łuckim od W. Samuela Rusina Beresteckiego WW. OO. Bonifratrom konwentu łuckiego sumy zł: 500 między innemi $[s]$ legacjami za duszę swoją uczynionemi $[s] \mathrm{z}$ oblaty $[s] \mathrm{z}$ grodu łuckiego testamentu w Ekstraktach dwóch.

No 2.

Roku 1700 dnia 2 grudnia $^{86}$ w grodzie łuckim od W. Jana Franciszka Charłęza i Katarzyny Charłęckich Małżonkom WW. OO. Bonifratrom konwentu łuckiego na sumę 3000 zł dóbr wsi Kiwierce niewiadomego obligu podniesioną z obowiązkiem płacenia po złotych 210 prowizji wyderkafowy w ekstrakcie będący $\underline{\text { Zapis }}$ [k. 9v]

No 3.

Roku 1750 dnia 18 marca w konsystorzu łuckim między WW. OO. Bonifratrami konwentu Łuckiego a W. Charłęckim Dóbr Rusinowego Beresteczka będący dziedzicem nakazujący zapłacenie prowizji od sumy 3500 złotych na tejże wsi Rusinowym Beresteczku będący

No 4.

Dekret

Roku 1766 dnia 4 lutego ${ }^{87}$ w grodzie łuckim od JW. Ludwika Bożydar[a] Podhorodeńskiego, Kasztelana Czern[ichowskiego] WW. OO. Bonifratrom konwentu

\footnotetext{
${ }^{83} \mathrm{~W}$ oryginale: Augusta.

${ }^{84} \mathrm{~W}$ oryginale: Januarij.

${ }^{85} \mathrm{~W}$ oryginale: Oktobra.

${ }^{86} \mathrm{~W}$ oryginale: Decembra.

${ }^{87} \mathrm{~W}$ oryginale: Februaryi.
} 
łuckiego na sumę zł 4000 niewyrażający obligu na wsi Korszowie ubezpieczający w oryginale będący Evictionis

Fascykuł 4-ty

No 1.

Roku 1708 dnia 15 listopada $^{88}$ od kahału morawickiego na Summę 1500 zł WW. Samuelowi i Katarzynie Steckim winną WW. OO. Bonifratrom konwentu łuckiego w Grodzie Łuckim oblatowany

No 2.

$\underline{\text { Zapis }}$

Roku 1709 d[nia] 13 stycznia ${ }^{89}$ w grodzie łuckim od WW. Samuela i Katarzyny Szaniawskich Siemiczów Steckich WW. OO. Bonifratrom konwentu łuckiego na sumę zł pol[skich] 1500 na kahale morawickim w powiecie dubieńskim lokowaną z obligacją odprawiania w miesiąc Mszy Świętych 2 z czytanemi [s] litaniami w oryginale zeznany Zapis

Dokumenty na kahale morawickim będący zł 1500 procesem prawnym w magistracie dubieńskim ewinkowanego ${ }^{90}$

[k. 10]

kahał morawicki wedle asekuracji 1819 r[ok]u d[nia] 16 lipca WW. OO. Bonifratrom łuckim dany z zaległego od tej sumy procentu zł 1124 dla tychże OO. Bonifratrów łuckich przyznał i procent od obydwóch sum po półczwarta od sta ${ }^{91}$ płacić obowiązał się, którego na rok wypada złotych 91 i groszy $28 \quad \underline{\text { Zapis }}$ Fascykuł 5-ty

No 1.

Roku 1681 dnia 11 lutego ${ }^{92}$ od W. Zachariasza Jana Szulca Kustosza Katedralnego Warmińskiego WW. OO. Bonifratrom konwentu łuckiego kamienicy ulrychawską zwanej w mieście Łucku położonej z obligacją Mszy Świętej jednej w tydzień za duszę rodziców i krewnych swoich

No 2 .

Zapis

Roku 1681 dnia 22 maja w konsystorzu łuckim od tegoż W. Szulca kanonika katedralnego warmińskiego WW. OO. Bonifratrom konwentu huckiego na tę kamienicę prawem natury sobie służącą fundationis w oryginale $\underline{\text { Zapis }}$ Fascykuł 6-ty

No 1.

Roku 1733 dnia 22 stycznia $^{93} \mathrm{w}$ grodzie łuckim od WW. OO. Bonifratrów konwentu łuckiego przeciw W. Kuleszę iż sumę po trzech latach oddać miał, nie oddał. Dobra swe zadłużył w pilności zaniesiony.

No 2.

Manifest

Roku 1729 dnia 14 grudnia $^{94}$ w grodzie łuckim od W. Franciszka Kuleszy, sędziego grodzkiego nowogrodzkiego $2000 \mathrm{WW}$. OO. Bonifratrom konwentu łuckiego leżący

$\underline{\text { Zapis }}$

\footnotetext{
${ }^{88} \mathrm{~W}$ oryginale: Novembra.

${ }^{89} \mathrm{~W}$ oryginale: Januar.

${ }^{90}$ Ewinkowany - wykazany, udowodniony.

${ }^{91}$ Liczone „od sta”, czyli od kosztów wytworzenia.

${ }^{92} \mathrm{~W}$ oryginale: Februaryi.

${ }^{93} \mathrm{~W}$ oryginale: Januar.

${ }^{94} \mathrm{~W}$ oryginale: Decembra.
} 
No 3.

Roku 1736 dnia 24 lipca $^{95}$ W. Leona Namińskiego WW. OO. Bonifratrom konwentu łuckiego sumę 1360 zł ręcznie sporządzony

Którego tegoż roku dnia 26 października ${ }^{96}$ w grodzie łuckim Oblata.

$\underline{\text { Zapis }}$

[k. 10v]

No 4.

Roku 1736 dnia 24 lipca $^{97}$ w grodzie łuckiem [s] od JW. Aleksandra Hrabi[ego] Krasickiego Halickiego WW. OO. Bonifratrom konwentu łuckiego na sumę złotych 1360 na dobrach wsi Jajno ${ }^{98}$ w powiecie kowelskim leżący zeznany $\underline{\text { Zapis }}$ Fascykuł 7-my

No 1.

Roku 1770 dnia 28 lipca $^{99}$ z akt grodzkich łuckich testamentu od W. Stefana Sebastiana Koziorowskiego, kanclerza łuckiego, który substancję swoją na różne klasztory dysponując WW. OO. Bonifratrom konwentu łuckiego zł 3000 legował wyjęty

Którego roku m[iesią]ca tychże w Grodzie Łuckim

Ekscerpt

No 2.

Oblata

Roku 1774 dnia 7 maja w sądach grodzkich łuckich między WW. OO. Bonifratrami konwentu łuckiego a JW. Franciszkiem Ledóchowskim, Starostą Włodzimierskim z drugiej strony zatrzymaną prowizją tylko zapłacić nakazujący zapadły Dekret No 3.

Roku 1763 dnia 20 lutego $^{100}$ od W Aleksandra Łubienieckiego L.O. ostatniej woli z rozporządzeniem swej substancji i WW. Bonifratrom konwentu łuckiego zł pol[skich] 1000 legujący z obligiem prawienia 12 Mszy Świętych i jednej egzekwii

Testament

No 4.

Roku 1777 dnia 30 sierpnia $^{101}$ w grodzie łuckim od W. Ludwika Radeckiego WW. OO. Bonifratrom łuckim na sumę zł pol[skich] 1000 testamentem W. Aleksandra Łubienieckiego na oblig legowaną na wsi Złoczów w powiecie dubieńskim leżącej zeznany

$\underline{\text { Zapis }}$

No 5.

Roku 1789 dnia 25 lutego $^{102}$ testamentu w grodzie łuckim od JW. Kajetana Wołczkiewicza Oliżara Stolnika Koronnego substancją dysponującego i WW. OO.

[k. 11]

Bonifratrom konwentu łuckiego summę zł pol[skich] 2000 na szpital legującego

Oblata

\footnotetext{
${ }_{95} \mathrm{~W}$ oryginale: Julij.

${ }_{96} \mathrm{~W}$ oryginale: Oktobra.

${ }^{97}$ W oryginale: Julij.

${ }^{98} \mathrm{~W}$ oryginale: Jayno.

${ }^{99}$ W oryginale: Julij.

${ }^{100}$ W oryginale: Februarij.

${ }^{101} \mathrm{~W}$ oryginale: Augusta.

${ }^{102} \mathrm{~W}$ oryginale: Februarij.
} 
No 6.

Roku 1890 dnia 24 lutego ${ }^{103}$ w grodzie łuckim od JW. Józefa Kalasantego Oliżara Szambelana Dworu Polskiego Orderu Św. Stanisława Kawalera WW. OO. Bonifratrom konwentu łuckiego na sumę zł 2000 na kluczu rafałowieckim w powiecie łuckim ubezpieczoną w ekstrakcie będący zeznany Evictionis Zapis No 7.

roku 1770 dnia 7 września ${ }^{104}$ w Łucku od W. Franciszka Rohozińskiego starosty łoweckiego, regenta grodzkiego łuckiego WW. OO. Bonifratrom konwentu łuckiego na sumę złotych 1514 groszy $20 \mathrm{z}$ obowiązkiem płacenia prowizji po siedem od sta rocznie dany w oryginale będący

Skrypt

Tegoż skryptu r[ok]u 1770 d[nia] 27 września ${ }^{105}$ w grodz[ie] łuck[im] Oblata Fascykuł 8-my

No 1.

Roku 1783 dnia 10 maja w grodzie łuckim od W. Pawła Bohusz Traczewskiego Burgrabiego Zamku Buł ${ }^{106}$ WW. OO. Bonifratrom konwentu łuckiego na sumę zł 2000 na dobrach wsi Bakowcach w powiecie łuckim [s] ubezpieczający w oryginale będący Evictionis [s]

$\underline{\text { Zapis }}$

No 2.

Roku 1802 d[nia] 8 października ${ }^{107}$ w sądach ziemskich dubieńskich między WW. OO. Bonifratrami konwentu łuckiego z jednej a W. śp. W-go Pawła Traczewskiego pozostałą wdową i innemi $[s] \mathrm{z}$ drugiej strony zostawiający sumę kapitalną [s] przy gruncie, a nakazujący zapłacenie prowizji, od którego założona została apelacja, zapadły

$\underline{\text { Dekret }}$

No 3.

Roku 1668 d[nia] 28 marca od prześwietnej kapituły łuckiej na plac za Bramą Kusznierską zwaną, pod wałem niedaleko żydowskiego skupiska leżący, w aktach konsystorza łuckiego roku 1669 dnia 13 grudnia ${ }^{108}$ oblatowany Zapis Fascykuł 9-ty

No 1.

Roku 1803 d[nia] 16 marca w sądach głównych guberni wołyńskiej drugiego Departamentu między WW. OO. Bonifratrami konwentu łuckiego z jednej, a WW. Traczewskiemi $[s] \mathrm{z}$ drugiej strony zapadły solutionis [k. 11v]

No 2.

R[ok]u 1689 dnia 26 grudnia od Najjaśniejszego Króla Jana III w Zamku Złotkiewskim WW. OO. Bonifratrom konwentu łuckiego na wolny urąb po J. Wazów

\footnotetext{
${ }^{103} \mathrm{~W}$ oryginale: Februarij.

${ }^{104} \mathrm{~W}$ oryginale: 7 bra.

$105 \mathrm{~W}$ oryginale: $7 \mathrm{bra}$.

106 Wyraz nieodczytany.

${ }^{107} \mathrm{~W}$ oryginale: Oktobra.

${ }^{108} \mathrm{~W}$ oryginale: Decembra.
} 
na tydzień w lasach Swozowskich ${ }^{109} \mathrm{w}$ powiecie łuckim znajdujących się danego roku 1725 dnia 18 stycznia w aktach grodzkich łuckich oblatowanego przywileju

No 3.

$\underline{\text { Ekstrakt }}$

Roku 1703 dnia 5 października ${ }^{110}$ od WW. Peretyatkowiczów na plac w Łucku sytuowany w aktach grodzkich łuckich oblatowany

$\underline{\text { Zapis }}$

No 4.

Roku 1784, dnia 19 stycznia ${ }^{111}$ między WJ. Księdzem Tadeuszem Łodzią Iwanowskim, Marcinem Wałęka Olszewskim sędzią i surogatem konsystorza łuckiego, kanonikami katedralnemi [s] łuckiemi $[s]$ od prześwietnej Kapituły Katedralnej Łacińskiej Łuckiej plenipotentami u WW. OO. Bonifratrami konwentu łuckiego gruntu niedaleko katedry przy ulicy idącej do klasztoru Ks.Ks. Karmelitów położonego, na grunt, klasztor i kościół Ś[więte]go Jakuba, dawniej parafialny w Łucku sytuowany w aktach konsystorza łuckiego

Fascykuł 10-ty

No 1.

Roku 1817, dnia 29 grudnia ${ }^{112}$ w aktach ziemskich łuckich testamentu od W. Marianny z Woroniczów Jakóbowskich, która substancją swoją na różne klasztory dysponując WW. OO. Bonifratrom konwentu łuckiego na restaurację szpitalu [s] zł 1000 legowała na dobrach Kluczu Iwańczyckim powiecie łuckim ubezpieczonej

Fascykuł 11-sty

No 1.

Roku 1821, dnia 17 sierpnia w aktach ziemskich łuckich od W. Marianny z Hulewiczów Falkowskiej WW. OO. Bonifratrom konwentu łuckiego na sumę zł 2290 i groszy 18 na dobrach wsi Kniahyniku w powiecie łuckim ubezpieczającej w oryginale będący

Fascykuł 12-sty

No 1.

Roku 1822, dnia 14 lutego z testamentu od WJ. Księdza Wykińskiego, kanonika katedralnego łuckiego, który substancję

[k. 12]

swoją na różne klasztory dysponując i WW. OO. Bonifratrom konwentu łuckiego zł pol. 3000 legował, która to suma w roku 1829 dnia 30 października ${ }^{113}$ wniesiona do Banku Monarszego na co w oryginale będący

Bilet

\footnotetext{
${ }^{109}$ Swozy.

${ }^{110} \mathrm{~W}$ oryginale: Oktobra.

${ }^{111} \mathrm{~W}$ oryginale: Januarii.

${ }^{112} \mathrm{~W}$ oryginale: Decembra.

${ }^{113} \mathrm{~W}$ oryginale: Oktobra.
} 
[k. 13]

\begin{tabular}{|c|c|c|c|c|c|}
\hline \multicolumn{6}{|c|}{ Tabela Sum Funduszowych Konwentu OO. Bonifratrów Łuckich } \\
\hline \multicolumn{2}{|c|}{ Kapitały } & \multicolumn{2}{|c|}{ Procentów } & \multirow[b]{2}{*}{$\begin{array}{l}\text { Od którego czasu i od Kogo nadane, } \\
\text { tudzież na jakich Dobrach umieszczone }\end{array}$} & \multirow{2}{*}{$\begin{array}{l}\text { Procent czy się } \\
\text { pobiera i od } \\
\text { dawnego czasu? }\end{array}$} \\
\hline Złote & $\begin{array}{l}\text { Gro- } \\
\text { sze }\end{array}$ & Złote & Grosze & & \\
\hline 7000 & & 245 & & $\begin{array}{l}\text { Od WJ Księdza Tyszki Kanonika } \\
\text { Katedralnego Luckiego Roku 1639, dnia } \\
12 \text { marca nadana na kahale łuckim } \\
\text { umieszczona }\end{array}$ & $\begin{array}{l}\text { Nie pobiera się } \\
\text { od roku } 1830\end{array}$ \\
\hline $\begin{array}{l}\mathrm{Z} \\
\text { placu }\end{array}$ & & 18 & & $\begin{array}{l}\text { Od WW. Peretyatkowiczów roku } 1667, \\
\mathrm{~d}\left[\text { nia] } 2 \text { lipca }{ }^{\mathrm{a}} \text { nadany, w najem }\right. \\
\text { wypuszczony }\end{array}$ & $\begin{array}{l}\text { Pobiera się od } \\
\text { roku } 1667\end{array}$ \\
\hline $\begin{array}{l}\mathrm{Z} \\
\text { placu }\end{array}$ & & 36 & & $\begin{array}{l}\text { Od Prześwietnej kapituły łuckiej r[ok]u } \\
\text { 1668, d[dnia] } 28 \text { maja nadany, w najem } \\
\text { wypuszczony }\end{array}$ & $\begin{array}{l}\text { Pobiera się od } \\
\text { roku } 1668\end{array}$ \\
\hline 9600 & & 336 & & $\begin{array}{l}\text { Od WJ Księdza Tyszki kanonika } \\
\text { kated[ralnego] łuck[iego] roku } 1670 \text {, } \\
\text { d[nia] } 3 \text { czerwca }{ }^{\text {b }} \text { dana u JW. Korze- } \\
\text { niowskiego na M. Mielnicy }\end{array}$ & $\begin{array}{l}\text { Pobiera się od } \\
\text { roku } 1670 \\
\text { Pobiera się od } \\
\text { roku } 1681\end{array}$ \\
\hline $\begin{array}{l}Z \\
\text { kamie- } \\
\text { nicy }\end{array}$ & & 666 & 20 & $\begin{array}{l}\text { Od W. Księdza Szulca, kan[onika] } \\
\text { kated[ralnego] huc[liego] r[oku] 1681, } \\
\text { d[nia] } 2 \text { września nadana na Kamienicy } \\
\text { w Łucku lokowana }\end{array}$ & $\begin{array}{l}\text { Pobiera się od } \\
\text { roku } 1681\end{array}$ \\
\hline 3500 & & 122 & 15 & $\begin{array}{l}\text { Od W. Samuela Rusina Beresteckiego } \\
\text { r[oku] } 1700 \text { d[nia], } 22 \text { września nadana } \\
\text { na Wsi Rusinowym Beresteczku }\end{array}$ & $\begin{array}{l}\text { Pobiera się od } \\
\text { roku } 1700\end{array}$ \\
\hline 2624 & & 91 & 28 & $\begin{array}{l}\text { Od W. Steckiego r[oku] 1709, d[nia] } 15 \\
\text { stycznia nadana, na kahale M. Murawi- } \\
\text { cy umieszczona }\end{array}$ & $\begin{array}{l}\text { Od roku } 1830 \\
\text { zalega }\end{array}$ \\
\hline 2000 & & 70 & & $\begin{array}{l}\text { Od Kuleszy r[oku] 1729, d[nia] } 14 \\
\text { grudnia nadana, na części wsi Borucho- } \\
\text { wa u W. Dziussy }\end{array}$ & $\begin{array}{l}\text { Pobiera się od } \\
\text { roku } 1729\end{array}$ \\
\hline 1300 & & 45 & 15 & $\begin{array}{l}\text { Od W. Kamińskiego r[oku] 1733, d[nia] } \\
20 \text { czerwca }^{c} \text { nadana na Wsi Jajno }{ }^{d} \text { w JW. } \\
\text { Krasickiego umieszczona }\end{array}$ & $\begin{array}{l}\text { Zalega od r[ok] } \\
\text { u } 1822\end{array}$ \\
\hline 4000 & & 140 & & $\begin{array}{l}\text { Od JW. Podhorodeńskiego r[oku] } 1766 \text {, } \\
\text { d[nia] } 14 \text { lutego nadana na wsi Korszo- } \\
\text { wie lokowana }\end{array}$ & $\begin{array}{l}\text { Pobiera się od } \\
\text { roku } 1766\end{array}$ \\
\hline
\end{tabular}

${ }^{\mathrm{a}} \mathrm{W}$ oryginale: July.

${ }^{\mathrm{b}} \mathrm{W}$ oryginale: Junij.

${ }^{\mathrm{c}} \mathrm{W}$ oryginale: Junij.

${ }^{\mathrm{d}} \mathrm{W}$ oryginale: Jaynie. 


\begin{tabular}{|c|c|c|c|c|c|}
\hline 3000 & & 150 & & $\begin{array}{l}\text { Od WJ Księdza Kozierawskiego, } \\
\text { kan[onika] katedr[alnego] łuc[kiego] } \\
\text { r[oku] 1770, d[nia] } 28 \text { lipca nadana u } \\
\text { JW. Zakrzewskiego na w[si]. Krupie, }\end{array}$ & $\begin{array}{l}\text { Pobiera się od } \\
\text { roku } 1770\end{array}$ \\
\hline 1000 & 28 & 35 & & $\begin{array}{l}\text { Od W. Radeckiego r[oku] } 1770 \text { d[nia] } \\
30 \text { sierpnia }^{e} \text { na części Wsi Złoczówą } \\
\text { umieszczona }\end{array}$ & $\begin{array}{l}\text { Pobiera się od } \\
\text { roku } 1770\end{array}$ \\
\hline 2627 & & 91 & 26 & $\begin{array}{l}\text { Od W. Bohozińskiego r[oku] } 1770 \\
\text { d[nia] } 27 \text { września nadana u JW. } \\
\text { Zonżeńskiego na części wsi Wołkowey }\end{array}$ & $\begin{array}{l}\text { Zalega od r[ok] } \\
\text { u } 1825\end{array}$ \\
\hline 20000 & & 700 & & $\begin{array}{l}\text { Od W. Traczewskiego r[oku] } 1783 \\
\mathrm{~d} \text { [nia] } 10 \text { maja nadana na wsi Bakow- } \\
\text { cach umieszczona }\end{array}$ & $\begin{array}{l}\text { Pobiera się od } \\
\text { roku } 1783\end{array}$ \\
\hline 2000 & & 100 & & $\begin{array}{l}\text { Od JW. Olizara r[oku] 1788, d[nia] } 26 \\
\text { Kwietnia, u JW. Narcyza Olizara na M. } \\
\text { Rafałowce }\end{array}$ & $\begin{array}{l}\text { Zalega od roku } \\
1830\end{array}$ \\
\hline 1000 & 18 & 60 & & $\begin{array}{l}\text { Od W. Jakubowskiego r[oku] } 1817 \text {, } \\
\text { d[nia] } 29 \text { grudnia nadana na Iwańczy- } \\
\text { cach u JW. Bystrego umieszczona }\end{array}$ & $\begin{array}{l}\text { Pobiera się od } \\
\text { roku } 1817\end{array}$ \\
\hline 2290 & & 114 & 7 & $\begin{array}{l}\text { Od W. Maryanny Falkowskiey r[oku] } \\
1821, \mathrm{~d}[\text { nia] } 17 \text { sierpnia nadana na wsi } \\
\text { Kniahyninka umieszczona }\end{array}$ & $\begin{array}{l}\text { Zalega od roku } \\
1826\end{array}$ \\
\hline 3000 & & 150 & & $\begin{array}{l}\text { Od WJ. Wykińskiego, kan[onika] } \\
\text { kat[edralnego] łuc[kkiego], r[oku] } 1822 \\
\text { dnia } 14 \text { nadana a w r[oku]. } 1829 \text { do } \\
\text { Banku Monarszego na procent wniesio- } \\
\text { na }\end{array}$ & $\begin{array}{l}\text { Zalega od roku } \\
1827\end{array}$ \\
\hline
\end{tabular}

[k. $13 \mathrm{v}]$

Przychód Roczny Klasztoru WW. OO. Bonifratr[ów]

\begin{tabular}{|c|c|c|}
\hline & Złote & Grosze \\
\hline $\begin{array}{l}\text { Od roku } 1831 \text {, dnia } 17 \text { grudnia było przychodów do roku } 1832 \text { dnia } 11 \\
\text { października }^{\mathrm{f}}\end{array}$ & 3228 & \\
\hline $\begin{array}{l}\text { Rozchód klasztoru i szpitalu tychże } \\
\text { OO. Bonifratrów }\end{array}$ & & \\
\hline Od roku tegoż 17 grudnia po ten czas było rozchodu & 2993 & 15 \\
\hline $\begin{array}{l}\text { Ato na utrzymanie zakonników i chorych, takoż sług i różne reparacje } \\
\text { budowali. }\end{array}$ & & \\
\hline Pozostaje w kasie & 234 & 15 \\
\hline
\end{tabular}

${ }^{\mathrm{e}} \mathrm{W}$ oryginale: Augusta.

${ }^{\mathrm{f}} \mathrm{W}$ oryginale: Oktobra. 
Słudzy Klasztorni

Jan Hniatiuk rodem $[s]$ z Gródka, z powiatu łuckiego mający lat 30, w obowiązku parobka

Kajetan Matusiewicz rodem z Borzemca, z powiatu łuckiego lat mający 17, na usługach klasztornych.

Antoni Hnaczuk rodem z Hulanik, powiatu łuckiego mający lat 30, za furmana.

Anna Kozakiewiczowa rodem z Włodzimierza, mająca lat 40, za kucharkę.

Marianna Parwacka rodem z Łucka, ma lat 45, za praczkę.

[k. 14]

Infirmeria

W infirmerii czyli szpitalu chorych utrzymuje się osób słabych sześć podług funduszu i eleemosyny ${ }^{114}$, czasem zaś i więcej. W czasie teraźniejszym są następujący.

\begin{tabular}{|c|c|c|c|c|c|c|}
\hline $\begin{array}{l}\text { Liczba } \\
\text { Słabych }\end{array}$ & Imiona Nazwiska & $\begin{array}{l}\text { Lata } \\
\text { Wieku }\end{array}$ & $\begin{array}{l}\text { Jakiego } \\
\text { wyznania }\end{array}$ & $\begin{array}{l}\text { Jakiej } \\
\text { klasy } \\
\text { (fiksacji) }\end{array}$ & $\begin{array}{l}\text { Gatunek } \\
\text { Słabości }\end{array}$ & $\begin{array}{l}\text { Czas } \\
\text { zostawania } \\
\text { w Kuracji. }\end{array}$ \\
\hline 1. & Felia Szaszkiewicz & 33 & $\begin{array}{l}\text { Rzymsko } \\
\text { Katolickiego }\end{array}$ & $\begin{array}{l}\text { Szlachcic } \\
\text { Wolny }\end{array}$ & Manie & $\begin{array}{l}\text { Od roku } \\
1829 \text { dnia } \\
25 \text { listopa- } \\
\text { da }^{\mathrm{g}}\end{array}$ \\
\hline 2. & Anton Czerczyk & 20. & Unickiego & Parobek & $\begin{array}{l}\text { Plica po- } \\
\text { lonica cum } \\
\text { Errisepelis }^{\mathrm{h}}\end{array}$ & $\begin{array}{l}\text { Od roku } \\
1829 \text { dnia } \\
25 \text { wrze- } \\
\text { śnia }^{i}\end{array}$ \\
\hline 3. & Adam Radziński & 67 & $\begin{array}{l}\text { Rzymsko } \\
\text { Katolickiego }\end{array}$ & Furman & Depernione $^{\mathrm{j}}$ & $\begin{array}{l}\text { Od } 1831 \\
\text { roku dnia } \\
19 \text { listopa- } \\
\mathrm{da}^{\mathrm{k}}\end{array}$ \\
\hline 4. & Józef Arnet & 12 & $\begin{array}{l}\text { Rzymsko } \\
\text { Katolickiego }\end{array}$ & $\begin{array}{l}\text { Szlachec- } \\
\text { kiego }\end{array}$ & $\begin{array}{l}\text { Mente } \\
\text { Captus }^{1}\end{array}$ & $\begin{array}{l}\text { Od } 1832 \\
\text { dnia } 28 \\
\text { lipca }^{\mathrm{m}}\end{array}$ \\
\hline
\end{tabular}

Pomienieni $[s]$ chorzy są leczeni podług przepisu doktora stosowną do swych słabości żywność mając. Posług w tem $[s]$ reguły sobie nadanej.

${ }^{\mathrm{g}} \mathrm{W}$ oryginale: Novembra.

${ }^{\mathrm{h}}$ Kołtun polski i róża.

${ }^{\mathrm{i}} \mathrm{W}$ oryginale: Septembra.

${ }^{\mathrm{j}}$ Odmrożenie.

${ }^{\mathrm{k}} \mathrm{W}$ oryginale: Novembra.

${ }^{1}$ Ograniczony umysłowo.

${ }^{\mathrm{m}} \mathrm{W}$ oryginale: Julij.

${ }^{114}$ Eleemosyna - łac. Jałmużna. 
[k. 15]

\begin{tabular}{|c|c|c|c|c|}
\hline \multicolumn{5}{|c|}{ Tabela obligów kościoła WW. OO. Bonifratrów łuckich } \\
\hline \multicolumn{2}{|c|}{$\begin{array}{l}\text { Poszczególnienie }[\mathrm{s}] \text { fundatora sumy i iakie z onej } \\
\text { dopełniają się obowiązki w roku }\end{array}$} & \multirow{2}{*}{$\begin{array}{l}\text { Msze } \\
54\end{array}$} & \multirow[t]{2}{*}{ Litanie } & \multirow[t]{2}{*}{$\begin{array}{l}\text { Aniver[sa- } \\
\text { rze] }\end{array}$} \\
\hline 10000 & $\begin{array}{l}\text { Od WJ. Księdza Baltazara Tyszki Kan[oni- } \\
\text { ka] Katedr[alnego] tuckiego za duszę } \\
\text { Baltazara odprawia się }\end{array}$ & & & \\
\hline 1000 & $\begin{array}{l}\text { Od WW. Feliciana i Dominika Dubieńskich } \\
\text { za duszę tychże odprawia się co miesiąc } \\
\text { Mszy czytanych jedna, co wynosi w Rok }\end{array}$ & 12 & & \\
\hline 1500 & $\begin{array}{l}\text { Od WW. Samuela i Katarzyny Szaniaw- } \\
\text { skich Steckich za duszę tychże odprawia się } \\
\text { co M[ie]siąc mszy czytanych dwie i Litanii } \\
\text { mówionych jedna przed Najśw[iętszą] } \\
\text { Panną, druga przed Panem Jezusem co } \\
\text { wyn[osi] }\end{array}$ & 24 & 24 & \\
\hline $\begin{array}{l}\text { W } \\
\text { kamienicy } \\
\text { ulrychow- } \\
\text { skiej }\end{array}$ & $\begin{array}{l}\text { Od W. Zachariasza Jana Szulca Kus. } \\
\text { Warmiński za duszę Jana i Rodziców jego } \\
\text { co tydzień msza odprawia się co wynosi w } \\
\text { rok }\end{array}$ & 52 & & \\
\hline \multirow[t]{4}{*}{1000} & $\begin{array}{l}\text { Od W. Aleksandra Łubienieckiego L.O. za } \\
\text { duszę Aleksandra odprawia się w rok }\end{array}$ & 12 & & 1 \\
\hline & $\begin{array}{l}\text { Oprócz wyż[ej] wyrażonych obligów } \\
\text { funduszowych z przepisu konstytucji } \\
\text { zakonnej za zmarłych księży, braci, } \\
\text { krewnych, przyjaciół i dobrodziejów } \\
\text { zakonu odprawia się w tydzień msza s. co } \\
\text { wynosi w Rok }\end{array}$ & 52 & & \\
\hline & $\begin{array}{l}\text { Na tęż intencja w suche dni podczas } \\
\text { adwentu odprawia się mszy } \\
\text { za każdego katolika umierającego w } \\
\text { szpitalu odprawia Msza 1, i Eksekwia za } \\
\text { każdego umierającego zakonnika Msza } \\
\text { Święta i Eksekwia }\end{array}$ & 2 & & \\
\hline & Ogół obligów trwałych & 208 & 24 & 1 \\
\hline
\end{tabular}




\begin{tabular}{|c|c|c|c|c|c|}
\hline & 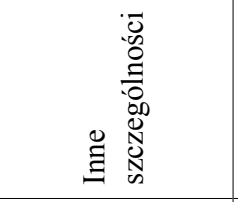 & & & & \\
\hline & 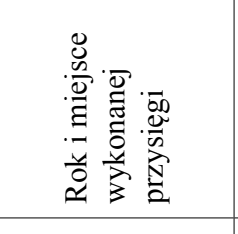 & 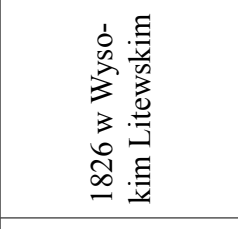 & 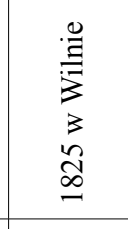 & 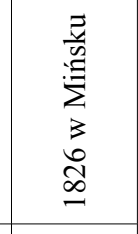 & 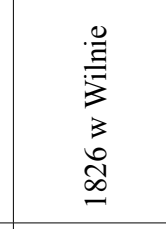 \\
\hline & 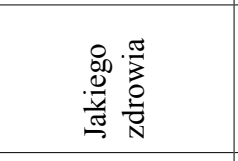 & $\begin{array}{l}\stackrel{8}{8} \\
: 0 \\
.00 \\
:\end{array}$ & $\begin{array}{l}\mathscr{D}_{0} \\
\stackrel{\Xi}{0} \\
\stackrel{0}{\Xi} \\
\end{array}$ & 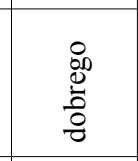 & 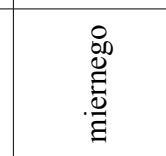 \\
\hline 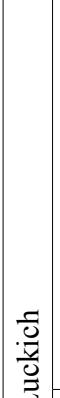 & 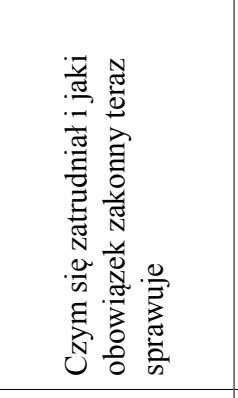 & 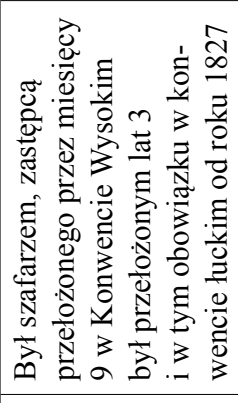 & 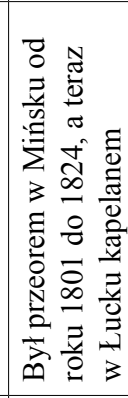 & 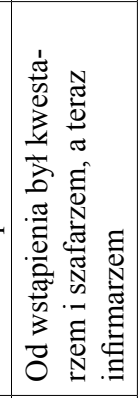 & 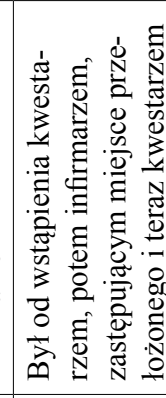 \\
\hline 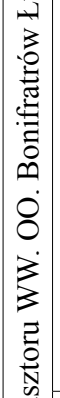 & 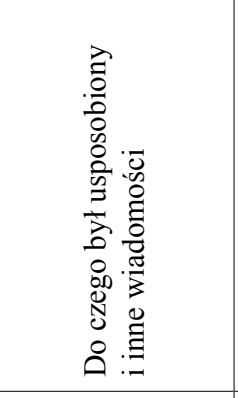 & 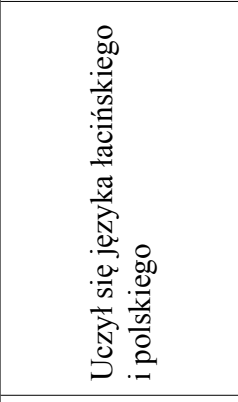 & 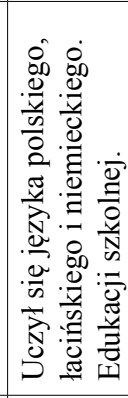 & 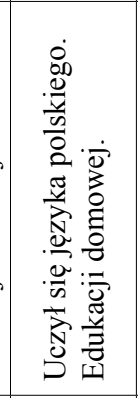 & 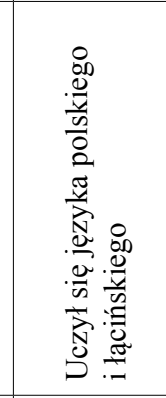 \\
\hline & 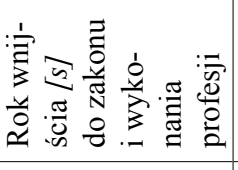 & 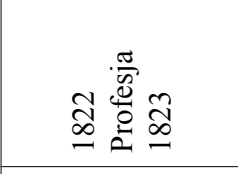 & 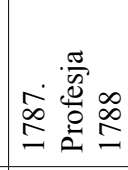 & 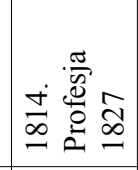 & 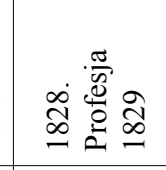 \\
\hline 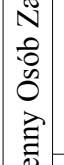 & 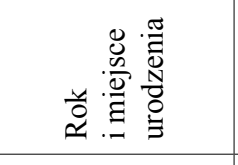 & 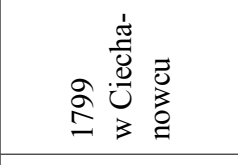 & 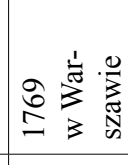 & 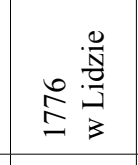 & 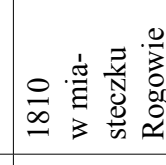 \\
\hline 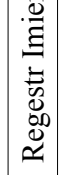 & 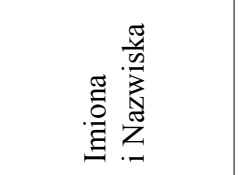 & 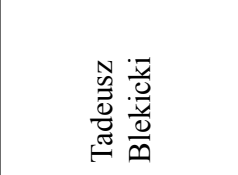 & 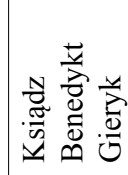 & 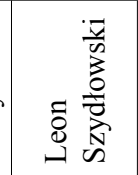 & 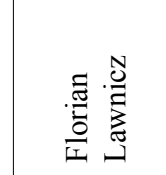 \\
\hline
\end{tabular}




\section{BIBLIOGRAFIA}

\section{Źródła}

Państwowe Archiwum Obwodu Żytomierskiego w Żytomierzu (DAŻO)

Fond. 90, op. 1, sp. 1011 Akt Wizyty Kościoła i Klasztoru OO. Bonifratrów Łuckich Za

Rok 1832 Uczyniony

\section{Opracowania}

Dębowska Maria, Łacińska parafia pod wezwaniem św. Jakuba Apostoła w Łucku (XVXVIII w.), Lublin 2014.

Dębowska Maria, Kościót i klasztor bonifratrów tuckich w świetle wizytacji generalnej z 1820 roku, w: Universitati serviens. Ksiega pamiatkowa ku czci Księdza Profesora Stanistawa Wilka SDB, red. J. Walkusz, M. Krupa, Lublin 2014, s. 85-94.

Dowbyszczenko Mychajło Wołodymyrowycz, Czenci-bonifratrijita ta poszyrennia humanistycznych idej na ukrajinśkych zemlach w perszij polowyni XVII st. (na Materiałach wołynśkoho wojewodstwa), Ukrajinoznawczyj almanach. Wypusk 5, Kyjiw 2011.

Dowbyszczenko Mychajło Wołodymyrowycz, Wolynska szlachta u relihijnych ruchach kincia XVI-perszoji polowiny XVII st., Kyjiw 2008.

Giżycki Jan Marek, Zniesione kościoty i klasztory rzymsko-katolickie przez rzad rosyjski $w$ wieku XIX-tym w diecezji tuckiej, żytomierskiej i kamienieckiej (gub. Wotyńskiej, kijowskiej i podolskiej), „Nova Polonia Sacra”, 1 (1928) s. 204.

Kołosok Bohdan Witalijowycz, Do istoriji budiwnyctwa w Łuccku chramiw sw. Jakowa, „Nowi Doslidżennia pamjatok kozaćkoji dobyw Ukrajini”, 5 (1996) s. 53-58.

Kołosok Bohdan Witalijowycz, Rymo-katołyćki swiatyni Łucka, Kyjiw 2004.

Orłowicz Mieczysław, Ilustrowany przewodnik po Wolyniu, Łuck 1929.

Poliszczuk Jurij Mykołajowycz, Etnokonfesijnapolityka rosijskoho caryzmu w Prawobereżnij Ukrajini (kinec XVIII — poczatok XX st,) Naukowi praci istorycznoho fakultetu Zaporiźkoho derżawnohoun uniwersytetu, Zaporiżżia-Proswita 2008.

Stownik geograficzny Królestwa Polskiego i innych krajów stowiańskich, red. F. Sulimierski, B. Chlebowski, W. Walewski, t. 5, Warszawa 1884.

Tronewycz Petro, Chilko Myełoła, Sajczuk Borys, Wtraczeni chrystyjanśki chramy Łuc$k a$, Łuck 2001.

Wojnicz Adam, Łuck na Wotyniu, Łuck 1922. 


\title{
CATHOLIC CHURCH OF ST JAMES AND THE MONASTERY OF THE BROTHERS HOSPITALLERS IN LUTSK IN 1832 IN A VISITATION ACCOUNT
}

\begin{abstract}
Summary
The Brothers Hospitallers were brought to Lutsk in 1638 on the initiative of the canon priest of the chapter, Rev. Baltazar Tyszka with the support of Bishop Andrzej Gembicki. However, the church of St Mary Magdalene and the monastery built at that time did not survive the fire that struck Luck in September 1781. It was then decided that the Church of St James, erected in the 16th century, was to be handed to them in exchange for the square where the convent had been located. The document of the foundation of the donated St James's Church is unknown. It is, however, known that it had been a parish church until it was given to the Brothers. The presented description of the church and monastery of the Brothers Hospitallers in Lutsk was drawn up in 1832 as part of a visitation by order of the Bishop of Lutsk and Zhytomyr, Michał Jan Piwnicki, and was written down by the canon of the Cathedral of Lutsk, Michał Sylwestrowicz. The source manuscript is currently stored in the State Archive of Zhytomyr Oblast in Zhytomyr under the reference number: fond. 90, op. 1, sp. 1011. The text is written in Polish. The writing is legible, regular and careful, without deletions or corrections. The act of visitation consists of 16 pages. The edition of the text was carried out according to the rules of the publishing instruction for historical sources from the 16th to mid-19th century by Kazimierz Lepszy, published in 1953 in Warsaw.
\end{abstract}

Keywords: Lutsk; St James's Church; the Brothers Hospitallers; canonical visitation 